\title{
Trajetórias, atributos e relações. Representações sobre redes e obtenção de trabalho ${ }^{1}$
}

\author{
Nadya Araujo Guimarães ${ }^{2}$, Ana Carolina Silva Andrada ${ }^{3}$, Monise \\ Fernandes Picanço ${ }^{4} \&$ Priscila Pereira Faria Vieira ${ }^{5}$ - Universidade de São Paulo \\ e Centro de Estudos da Metrópole- Brasil
}

\begin{abstract}
Resumo
O texto analisa os mecanismos pelos quais os indivíduos têm acesso a oportunidades de emprego e como, para tal, acionam os seus contatos pessoais. Argüi-se a importância de entender o modo como os mesmos interpretam os seus percursos sócio-ocupacionais e estabelecem alvos com respeito ao trabalho para bem interpretar as maneiras pelas quais acionam suas redes e o lugar que lhes conferem na busca por emprego. O argumento é ilustrado com a análise de oito casos, retirados de uma pesquisa mais ampla com demandantes de trabalho em agências de emprego da região metropolitana de São Paulo; este estudo combinou um survey por amostra representativa com 1507 casos, em 2004, e uma pesquisa qualitativa, entre 2009 e 2010, que coletou 29 entrevistas biográficas e mapeou as redes de uma sub-amostra de casos-tipo, selecionados dentre os que haviam respondido o questionário em 2004.
\end{abstract}

Palavras-chave: redes sociais - mercado de trabalho - trajetórias - Brasil.

\begin{abstract}
The article aims at contributing to recent analysis on how people get access to job opportunities and the role of different mechanisms mobilized on it, with special interest in personal contacts. We argue that job search decisions are grounded in individual interpretations and meanings; decisions on if and how personal networks are mobilized in the job search depend upon the ways job seeker interpret his own social and occupational trajectory and establish professional targets. Therefore research designs have to take into account the characteristics related to individual attributes, networks and trajectories, exploring how those three dimensions interact. In order to illustrate this argument, eight cases were selected from a

\footnotetext{
${ }^{1}$ Este texto é uma versão significativamente revista e bastante ampliada da comunicação "Redes sociais e obtenção de trabalho. Trajetórias, atributos e relações", discutida quando do XI Congresso Luso-AfroBrasileiro de Ciências Sociais (Salvador, 8-10 de agosto de 2011). Nele apresentamos alguns dos resultados do projeto "Redes sociais e obtenção de trabalho: os mecanismos não mercantis na operação do mercado de trabalho", que se desenvolve no Centro de Estudos da Metrópole com financiamentos da Fapesp (Programa CEPID, proc. n¹998/14342-9 e Programa INCT proc. 2008/57843-1) e do CNPq (Edital Universal, proc. 481268/2004-9 e Programa INCT proc. 573864/2008-0). As autoras agradecem o apoio de Miranda Zoppi, Mariel Serapião, Barbara Vazquez, Jonas Bicev, Ivo Costa e João Paulo Santoro, outros membros da equipe de pesquisa que se envolveram ativamente nas etapas de desenho do levantamento de campo, coleta e preparo dos dados aqui analisados. Agradecem igualmente a Eduardo Marques e a Charles Kirschbaum, bem como ao parecerista anônimo da revista Redes, cujos comentários e sugestões nos ajudaram não apenas a aprimorar o argumento e o uso das evidências tal como aqui apresentados, como a descortinar novas idéias e desenvolvimentos analíticos que, pelo objeto priorizado neste texto, certamente nos animarão a explorá-los em nossos próximos escritos.

2 nadya@usp.br. Dept. Sociologia.

3 caandrada@gmail.com

${ }^{4}$ monise.picanco@gmail.com

${ }^{5}$ prifariavieira@yahoo.com.br
} 
REDES- Revista hispana para el análisis de redes sociales

Vol.22,\#6, Junio 2012

http://revista-redes.rediris.es

broader research conducted with job seekers on employment agencies in the metropolitan area of São Paulo, Brazil. The study combined two methodological approaches: in a first phase, conducted in 2004, a sample survey explored 1507 individual profiles and trajectories; in a second phase, between 2009 and 2010, a qualitative research was carried out with a subsample of 26 respondents selected among the first phase interviewees. Biographical interviews allowed collecting their occupational trajectories and mapping their personal networks.

Key words: social networks - labour market - trajectories - Brazil.

\section{Introdução}

O acesso a oportunidades de emprego, um tema recorrente no campo dos estudos de trabalho, se constitui no objeto deste texto. Seu partido analítico, entretanto, difere do modo usual, que costuma equacionar o problema pela ótica da estrutura da oferta de lugares no mercado de trabalho.

Sem duvidar da importância deste enfoque, pretendemos produzir resultados de pesquisa que nos permitissem melhor entender como as chances de inclusão no mundo do trabalho

- são figuradas pelos indivíduos como possíveis,

- são por eles tornadas prováveis, vale dizer são acionadas,

- sendo, por fim, efetivamente construídas no curso das suas trajetórias.

Assumimos que esse é um movimento em que se mobilizam (reflexivamente), e se articulam, atributos individuais e estruturas relacionais. Nem um, nem outro tem relação necessária, putativa, com o resultado final, a saber, com a obtenção (ou não) de trabalho, ou com a qualidade (maior ou menor) da ocupação lograda. Ademais, mobilização e articulação de atributos estão imersas na dinâmica biográfica das trajetórias individuais, que não são redutíveis aos seus percursos ocupacionais, mas que envolvem outros tipos de percursos (migratórios, reprodutivos, escolares, só para citar alguns).

Esse nosso partido interpretativo tem como benefício trazer para o centro da agenda dos estudos sobre o mercado de trabalho a análise das relações sociais que, numa escala micro, sustentam a operação desse mercado. Tais relações são tecidas por indivíduos particulares (porque esculpidos por biografias singulares), e são construídas em distintos espaços de sociabilidade. Com base neste enfoque, hipotetiza-se que, sob um mesmo contexto estrutural, as chances de obtenção de trabalho variam não apenas em função das mudanças na estrutura da oferta de postos, ou da variada natureza dos atributos individuais daqueles que os pleiteiam, 
REDES- Revista hispana para el análisis de redes sociales

Vol.22,\#6, Junio 2012

http://revista-redes.rediris.es

mas estão associadas, como fartamente demonstrado, à natureza das redes em que os indivíduos se inserem e, sobretudo - e este será o ponto central ao argumento aqui desenvolvido -, refletem o modo como atributos e relações são representados, mobilizados e negociados nas situações de procura de trabalho.

Com efeito, estudos pioneiros que se detiveram na análise do caso brasileiro já documentaram (Marques, 2010) que os padrões de conexão expressos nas redes pessoais não exaurem as explicações sobre as condições de vida, ainda que sejam de grande valia para ajudar a entendê-las. Por isso mesmo, para que possamos analisar a situação dos indivíduos no mercado de trabalho, é imprescindível não só conhecermos suas redes pessoais, mas principalmente a articulação dessas com as trajetórias de vida dos trabalhadores.

O argumento será ilustrado com a análise de oito casos, retirados de uma pesquisa mais ampla com demandantes de trabalho em agências de emprego da região metropolitana de São Paulo. Para o desenvolvimento desse estudo combinaram-se duas estratégias de pesquisa: inicialmente, um survey por amostra representativa com 1507 casos foi realizado em 2004; a ele se seguiu uma pesquisa qualitativa, que teve lugar entre 2009 e 2010 , no curso da qual foram coletadas 29 entrevistas biográficas e mapeadas as redes de uma sub-amostra de casos-tipo, selecionados dentre os que haviam respondido o questionário em 2004.

Para melhor organizarmos as evidências empíricas coletadas, o artigo se estruturará em quatro partes, alem desta "Introdução". Na primeira, retomamos a importância do tema e da abordagem para os estudos sobre mercado e procura de trabalho, notadamente tendo em vista a agenda e avanços da sociologia do trabalho no Brasil. Na segunda, analisaremos o primeiro grupo de quatro casos, ilustrando como atributos e relações se articulam em exemplos de configurações de percurso laboral conducentes à (re)produção da vulnerabilidade ocupacional. Na terceira, faremos igual movimento observando outros quatro contextos biográficos em que atributos e relações parecem consorciar-se para produzir a (relativa, ao menos) estabilidade ocupacional. Finalmente, na quarta e última parte, alinharemos alguns argumentos, à guisa de conclusão e como forma de alimentar possíveis desdobramentos com vistas a novas indagações de pesquisa.

\section{As micro-relações e as oportunidades ocupacionais: desafios teórico-metodológicos ao campo dos estudos do trabalho}


REDES- Revista hispana para el análisis de redes sociales

Vol.22,\#6, Junio 2012

http://revista-redes.rediris.es

Extensa literatura internacional tem documentado a importância das redes para o entendimento da dinâmica do mercado de trabalho, seja tomando o partido disciplinar da economia, seja seguindo os cânones da sociologia. Nesta, classicos seminais (como Granovetter 1973, 1983, 1988 e 1994) fertilizaram um campo que não tem cessado de produzir novos estudos e reflexões densos e consistentes. ${ }^{6}$ Eles têm explorado o potencial explicativo das redes, desvendando uma pluralidade de dimensões, dentre as quais destacaríamos aquelas relativas:

- aos processos de recrutamento (Fernandez e Weinberg, 1997; Petersen, Saporta et al, 2000);

- ao efeito do tipo de vínculo sobre o acesso ao trabalho (Bian, 1997; Ioannides e Loury, 2004; Yakubovich, 2005; Tassier, 2006),

- ao processo de emparelhamento (matching) entre demandantes e ofertantes (Fernandez e Sosa, 2006; Stovel e Fountain, 2008; Barr, 2009; Mc Donald, 2010),

- à performance e progressão nas carreiras (Podolny e Baron, 1997; Moerbeek e Need, 2003; Neckerman e Fernandez, 2003; Castilla, 2005) e à mobilidade socio-ocupacional (Lin, Ensel e Vaughn, 1981; Davern e Hachen jr, 2006),

- aos impactos dos tipos de vínculos sobre os rendimentos obtidos no trabalho e os padrões de desigualdade deles resultantes (Weneger, 1991; Elliot, 1999; Mouw, 2003; Carvó-Armengol e Jackson, 2004; Franzen e Hangartner, 2006; Tassier, 2006), com especial atenção ao efeito de marcadores sociais como raça e gênero (Seidel, Polzer e Stewart, 2000; Huffman e Torres, 2002; McDonald, Lin e Ao, 2009),

- ou mesmo aos contextos institucionais em que os indivíduos procuram ou obtêm trabalho, aí compreendidas as características da relação entre empresa e escola (Brinton e Kariya, 2001) ou a introdução de reformas de mercado em antigas economias socialistas (Gerber e Mayorova, 2010) e suas implicações para o modo como as redes têm sido acionadas na busca e obtenção de trabalho.

\footnotetext{
${ }^{6}$ Transcende o objetivo deste texto fazermos uma revisão sistemática dessa ampla literatura, o que o transformaria numa resenha, provavelmente útil mas cujo resultado se superporia, competindo, com o alvo maior que perseguimos. Isso porque, e como dito acima, interessa-nos, aqui, documentar, à luz de um estudo empírico, o valor heurístico de observarmos os relatos sobre procura e obtenção de trabalho de um ponto de vista especial, a saber: tendo em conta o modo pelo qual, em distintos momentos da sua trajetória biográfica, os indivíduos representam suas chances e recursos para inclusão no mercado de trabalho, de maneira a - embebidos dessas representações -, acionarem (ou não) as suas redes de contatos pessoais.
} 
REDES- Revista hispana para el análisis de redes sociales

Vol.22,\#6, Junio 2012

http://revista-redes.rediris.es

Para o caso brasileiro, entretanto, estamos longe de poder reconhecer uma tal riqueza de resultados. É certo que desde o texto precursor de Durham (1973), com seus achados inspiradores sobre trajetórias de migrantes nordestinos e inserção no mercado de trabalho de São Paulo, estabeleceu-se, de maneira irretorquível, a relevância analítica desse campo. Dela, entretanto, não decorreu o vigor observado internacionalmente, nem no que respeita à pluralidade de dimensões trazidas para análise, nem no que concerne à precisão e aos avanços nos modos de mensuração. ${ }^{7}$

Todavia, não é objeto deste texto ilustrar, para o caso brasileiro, aquilo já fartamente documentado na literatura internacional, ou seja, que os contatos importam para entendermos o acesso e reparto de oportunidades no mercado de trabalho. Pretendemos, antes, ir adiante e documentar como eles importam. Explorar sua relação com os atributos individuais, com a capacidade de agência dos indivíduos na sua busca por trabalho e com os caminhos que os atores imprimem, pouco a pouco, às suas trajetórias ocupacionais. Nesse sentido, atributos e relações ganham força explicativa se tomados no enlace entre biografia, ação e representações.

Para dar conseqüência a esse interesse teórico, desenhamos um estudo baseado em entrevistas que combinaram um levantamento biográfico e técnicas de mapeamento de redes. O primeiro tinha como eixo organizador recolher informações sobre o percurso ocupacional e os modos de aquisição de trabalho. Já as técnicas de análise de rede nos facultavam reunir evidências sobre os modos pelos quais a sociabilidade cotidiana dos indivíduos se relacionaria ao seu processo de busca por trabalho.

As entrevistas, realizadas entre 2009 e 2011, foram feitas com uma sub-amostra de indivíduos, que responderam a um survey sobre procura de trabalho, conduzido em agosto de 2004 na Região Metropolitana de São Paulo. ${ }^{8}$

\footnotetext{
${ }^{7}$ Não obstante, resultados mais robustos podem ser encontrados nos estudos sobre redes, dinâmica econômica e comportamento organizacional, com especial relevo para os estudos relativos seja ao campo organizacional (que têm no trabalho de Kirschbaum, 2006 sobre a indústria brasileira de filmes um belo exemplo), seja relativos ao empreendedorismo etnico (com exemplos igualmente destacáveis dos trabalhos de Martes e Rodriguez, 2004 e Truzzi e Sacomano Neto, 2007). Curiosamente, essa vaga de novas analises pouco ecoou até aqui, no Brasil, no que se refere ao estudos dos elos entre redes, dinâmica econômica e comportamento dos atores no que concerne ao mercado de trabalho.

${ }^{8}$ A sub-amostra compos-se de 100 casos aos quais foram somados outros 100 para fins de reposição. Tal necessidade resultava de que voltáramos a procurar pelos respondentes em 2009, cinco anos após o contato inicial, pelo que havia o risco de que não os reencontrássemos, ou mesmo que alguns já não se dispusessem a participar do novo estudo. Isso porque esse grupo de casos foi extraido de um conjunto de 1507 respondentes que tomaram parte do survey "À Procura de Trabalho", um estudo conduzido junto a indivíduos em procura de emprego em agências (estatais, sindicais e privadas), em São Paulo, maior mercado metropolitano de trabalho no Brasil. O levantamento compreendeu três planos amostrais
} 
REDES- Revista hispana para el análisis de redes sociales

Vol.22,\#6, Junio 2012

http://revista-redes.rediris.es

A primeira parte da entrevista, de caráter biográfico e qualitativo, recompunha, através de uma série de perguntas abertas, a trajetória ocupacional do entrevistado e os modos de aquisição de trabalho em cada experiência. Pesquisava também as suas práticas de sociabilidade. Buscava-se, assim, caracterizar o entrevistado do ponto de vista de seus atributos pessoais e da sua trajetória de vida, além de colher representações sobre o significado que ele conferia à sua experiência pretérita no mercado de trabalho e às suas iniciativas com vistas à procura de emprego.

Já a segunda parte se propunha a identificar a rede de cada informante, tal como ele a representava no momento da entrevista. Essa etapa possibilitava o mapeamento e caracterização da sua rede de relações pessoais em suas diferentes esferas de sociabilidade; estas são entendidas, aqui, como o "produto da especialização das atividades sociais e humanas em sentido amplo, incluindo círculos de interesse (círculos de discussão e de práticas específicas), círculos de sociabilidade e convivência (grupos de amigos) e instituições específicas (como a família)" (Marques et al, 2006). ${ }^{9}$ Nessa parte da entrevista foram aplicados um questionário gerador de sementes e um questionário gerador de nomes. ${ }^{10}$

A entrevista finalizava-se com um conjunto de perguntas complementares que nos permitiam identificar, na sua rede, as pessoas que o entrevistado considerava especialmente importantes enquanto propiciadores de apoio, de "ajudas" (termo nativo que retivemos na condução da entrevista), em quatro domínios da sua vida cotidiana; sendo importantes:

(com amostras estratificadas, para cada um dos tipos de agencia, proporcionais ao seu tamanho) e adotou como técnica de seleção a amostragem probabilística em dois estágios (por conglomerados). Os respondentes foram classificados em 11 diferentes tipos, gerados a partir da técnica GoM - Grade of Membership, que os grupou segundo um leque de cerca de sessenta variáveis, que abarcavam atributos pessoais, características da familia de origem, da inserção ocupacional, da trajetória no mercado de trabalho, dos modos de procura e obtenção de emprego, e das suas percepções sobre o papel de redes na organização da sua vida e superação de problemas (para maiores detalhes sobre a construção dessa tipologia e sobre os grupos de casos dela resultantes ver Guimarães e Melo, 2009). Os 100 indivíduos selecionados para o presente estudo (tanto quanto os 100 casos de reposição) foram sorteados dentre aqueles que se dispuseram a participar da continuidade da pesquisa ( $80 \%$ dos entrevistados iniciais aceitaram seguir no estudo), garantindo a presença de entrevistados provenientes de todos os 11 grupos da tipologia GoM. Do total de casos sorteados, 79 foram re-localizados e 29 entrevistas puderam ser até aqui finalizadas como parte da nova fase da pesquisa. Dentre essas, selecionamos os 8 casos de que trataremos neste texto.

${ }^{9}$ Não coletamos redes egocentradas. Optamos pela identificação de redes pessoais, que incluem os contatos que distam mais que um passo de ego; nesse sentido, não limitamos a abrangência da rede em que o individuo está inserido.

${ }^{10}$ O questionário "gerador de sementes" foi elaborado a partir das esferas de sociabilidade referidas pelo entrevistado na primeira parte da entrevista e checadas no início da segunda parte, perguntando ao entrevistado cinco nomes de pessoas importantes em cada uma dessas esferas. A partir dos nomes citados como "sementes", pedíamos ao entrevistado que nomeasse mais três pessoas que fossem, ao mesmo tempo, ligadas a uma dessas "sementes" e também a ele. Seguíamos essa dinâmica até esgotar os nomes das sementes, repetindo-a para cada nome novo que aparecesse, até que os novos nomes se esgotassem. Por fim, classificávamos cada um dos nomes de acordo com esfera de sociabilidade a que se vinculara, o contexto de início do vínculo e o seu local de residência. 
REDES- Revista hispana para el análisis de redes sociales

Vol.22,\#6, Junio 2012

http://revista-redes.rediris.es

- por sua capacidade de ajudar nas iniciativas do entrevistado no mercado de trabalho, seja (i) fornecendo informações de (ou indicações para) oportunidades de trabalho' ${ }^{11}$; seja (ii) por fornecerem informações de (ou indicações para) oportunidades de trabalho que se tornaram efetivas, isto é, que foram conquistados pelo entrevistado;

- por proverem outros tipos de suporte para a vida do entrevistado, seja (iii) fornecendo ajuda para problemas ordinários do dia-a-dia, "quebrando-galhos" no cotidiano, seja, e finalmente, (iv) por serem requisitadas para fornecer ajuda em questões (ou momentos) cruciais da vida do entrevistado.

Com isso pretendíamos captar e distinguir as pessoas - ou os "nós" -, de sorte a não apenas identificá-las, mas também de maneira a distingui-las pela fonte/razão/domínio do qual decorria essa sua importância.

Para a construção da nossa argumentação decidimos partir de dois casos, os de Dulcinéia e Sandra ${ }^{12}$. Tomando em consideração apenas os atributos das suas redes pessoais, elas em muito pouco se diferenciariam. Ambas possuem redes médias (vis-à-vis aos demais casos): a de Sandra com 45 contatos e 228 vínculos entre os nós (isto é, entre os indivíduos citados pelo entrevistado como contato), e a de Dulcinéia com 43 contatos e 210 vínculos entre os nós. ${ }^{13} \mathrm{~A}$ densidade dessas duas redes é também praticamente a mesma: 0,1101 e 0,1110, respectivamente. ${ }^{14}$ Ademais, são redes que podem ser descritas a partir de vínculos tecidos em um leque de espaços de sociabilidade igualmente similar; 8 e 7 diferentes esferas de sociabilidade resumem e organizam, respectivamente, os contatos de Sandra e de Dulcinéia. Dessas esferas, um numero também similar (4 e 3, respectivamente) diz respeito àquelas que denominamos "esferas institucionais", nas quais a sociabilidade acontece em espaços públicos, onde é mais provável a convivência

\footnotetext{
${ }^{11}$ Neste texto, mais das vezes, consideraremos equivalentes as expressões "indicação" e "fornecimento de informação", conquanto saibamos tratarem-se de formas diferentes de acesso a oportunidades no mercado de trabalho. No primeiro caso, o da "indicação", estamos frente a formas de acesso a empregos que implicam mobilização da reputação de quem indica, ou que envolvem relações de confiança entre o indivíduo que indica o candidato e aquele que oferece a vaga. No segundo caso, o do "fornecimento de informação", tais circunstancias não estão em jogo, tratando-se, antes, da partilha de uma "dica", da mera circulação de informação sobre uma chance de trabalho.

12 Estes, como todos os outros nomes próprios referidos ao longo do texto são fictícios, para melhor resguardarmos a identidade dos nossos entrevistados.

13 Dentre os casos estudados, as redes variavam significativamente por seu tamanho; a menor era formada por 24 nós e a maior por 123. As redes foram divididas em pequenas (até 31 nós), médias (entre 33 e 55 nós) e grandes (60 nós ou mais).

${ }^{14}$ A densidade de uma dada rede é a proporção entre os vínculos realmente existentes e o total de vínculos possíveis de serem estabelecidos entre seus nós, podendo variar entre 0 e 1 . A densidade da rede tende a ser menor quanto maior o tamanho da rede. Nos casos de Sandra e Dulcinéia a densidade de 0,11 , conquanto muito distante do máximo possível, se mostrara reletivamente elevada haja visto o que encontramos para os demais casos.
} 
REDES- Revista hispana para el análisis de redes sociales

Vol.22,\#6, Junio 2012

http://revista-redes.rediris.es

entre diferentes ${ }^{15}$. Além disso, Sandra e Dulcinéia mostram, em seus contatos, a mesma propensão à homofilia, ou seja, a se relacionar com pessoas similares a elas próprias (Mcpherson, Smith-Lovin, Cook, 2001); tomando-se por exemplo o sexo daqueles com quem tecem laços, em 60 e $65,12 \%$ dos casos, respectivamente, os seus vínculos se estabelecem com outras mulheres. ${ }^{16}$

No que concerne a seus atributos pessoais, é certo que elas apresentam algumas diferenças em sua condição migratória, idade e posição na família. Sandra é paulistana, mais jovem (28 anos no momento do reencontro com nossa equipe), solteira e não tem filhos; já Dulcinéia é migrante, mais velha (39) e chefe de uma família mono-parental, com um filho adolescente. Apesar disso, elas têm semelhanças em outras dimensões igualmente importantes para a nossa análise. Ambas são negras e moram na zona sul da cidade de São Paulo, em bairros considerados socialmente vulneráveis. As duas possuem ensino médio completo, conquanto Dulcinéia tenha feito curso técnico de radiologia. Convergem também no intenso transito entre ocupações, indicativo de trajetórias ocupacionais em que são escassos os eventos de longa duração.

Todavia, mesmo com tantas características a aproximá-las, são distintos os percursos e resultados logrados por Sandra e Dulcinéia no mercado de trabalho. Enquanto a primeira possui uma trajetória relativamente ascendente, a segunda tem um percurso marcado pela vulnerabilidade. Dois casos intrigantes, que desafiam juízos analíticos apressados no esforço por explicar o acesso a oportunidades de trabalho reduzindo-o, explicativamente, a relações unilaterais, seja com os atributos individuais, seja com as redes relacionais. Esses dois casos nos obrigam a um movimento diverso. Ao enfrentarmos a análise em profundidade dos mesmos quisemos explorar o modo como se articulam, em diferentes biografias, os mecanismos que levam a resultados ocupacionais diversos.

Entretanto, seria um contra-senso reduzirmos o espaço de variabilidade a apenas duas configurações singulares. Por isso mesmo, nosso segundo passo analítico, na construção deste texto, foi mostrar como cada uma dessas "configurações básicas" (Dulcinéia e Sandra), distintas em seus desfechos, comportam "variantes" que

\footnotetext{
${ }^{15}$ Exemplos dessas interações institucionalizadas em espaços que são dominantemente públicos podem ser encontrados nas esferas religiosa, escolar e ocupacional.

16 Ora, uma rede cujos nós têm características iguais às de ego (mesmo sexo, ou mesmo local de moradia, ou mesma ocupação, etc.) tende a ter chances mais reduzidas no sentido de fazer circular novos bens ou recursos, dentre eles informações sobre oportunidades de trabalho. Isso porque sendo maior a probabilidade de acesso a informações redundantes, menor será a capacidade de difusão de informações diversificadas.
} 
REDES- Revista hispana para el análisis de redes sociales

Vol.22,\#6, Junio 2012

http://revista-redes.rediris.es

elucidam novos modos particulares de tecer os elos entre atributos, relações e trajetórias.

Desse modo, na sessão subseqüente, e tomando Dulcinéia como ponto de partida, seguiremos explorando outros casos significativos (os de Francisco, Vanda e Deise), que ilustram modos distintos (ao de Dulcinéia) de articular esses mesmos determinantes, produzindo um mesmo resultado, a vulnerabilidade ocupacional. Em seguida, uma outra sessão fará o mesmo percurso analítico, só que tomando o caso de Sandra como configuração básica; para enriquecê-la, vamos recorrer a outras três variantes (Elisabete, Rogério e Damaris), que com ela compartilham o mesmo resultado no plano ocupacional, o de uma certa estabilidade, tecida, entretanto, em cada uma delas, por diferentes formas de ir articulando, ao longo de suas biografias, perfis individuais e experiências relacionais.

\section{A produção da vulnerabilidade: os modos de articular atributos e relações em quatro contextos biográficos. Dulcinéia, Francisco, Vanda e Deise}

"Eu queria ser qualquer coisa, menos onde eu "tô" hoje. Mas... - incrível! continuo no mesmo lugar. Quer dizer, eu só estudei, né?... me preparei, mas... (Dulcinéia, 39 anos)"

Dulcinéia é uma sergipana, negra, nascida em Tobias Barreto. Tinha 39 anos, quando a entrevistamos em 2010. A sua trajetória ocupacional (ou, quando menos, aquilo que ela concebe como sua trajetória "de trabalho") se iniciara apenas aos 19 anos, em sua primeira tentativa de migração para São Paulo. Sua primeira ocupação foi obtida com a ajuda de um primo, que a indicou para trabalhar em uma padaria. Entretanto, Dulcinéia permaneceu pouco tempo em São Paulo, e voltou à sua cidade de origem depois de seis meses. No ano seguinte, a entrevistada retornou à capital paulista, já com emprego assegurado. Uma de suas irmãs, que a precedera na migração, a havia indicado para uma oportunidade como empregada doméstica, com carteira assinada.

A biografia de Dulcinéia é perpassada por ocupações ligadas ao serviço de limpeza e/ou àqueles serviços que não necessitam qualificação. Afora os trabalhos como diarista que, juntos, somam 12 anos da sua trajetória, seus cinco empregos registrados são (ou se iniciaram) na limpeza, e três deles foram exercidos em casas de família. Dentre os mecanismos para chegar às oportunidades de trabalho, 
REDES- Revista hispana para el análisis de redes sociales

Vol.22,\#6, Junio 2012

http://revista-redes.rediris.es

domina a "indicação" (direta ou intermediada por informação de um terceiro); quatro dos seus cinco trabalhos registrados foram assim conseguidos, bem como pelo menos dois dos seus trabalhos como diarista e os outros dois trabalhos não ligados à limpeza.

Ao longo dos vinte anos em que mora na cidade de São Paulo, Dulcinéia investiu na sua educação; terminou o ensino médio e fez um curso técnico de Radiologia. Entretanto, até meados de 2010, não havia conseguido trabalho na área em que se qualificou. Uma das razões para essa dificuldade é explicitada pela própria entrevistada: o mercado de trabalho na área de Radiologia é bastante "fechado". Sua procura tem se dado através da internet ou pedindo ajuda a antigos colegas que, a seu juízo, têm contatos na área. Ela tem consciência da importância dos contatos, dos quais não dispõe, razão pela qual nada conseguira até aquele momento.

"Entrevistadora - E nessa área, na área de radiologia, você falou que procura por site e por indicação...

Dulcinéia - Isso, é mais por indicação.

Entrevistadora - Mas já teve alguma indicação? Assim, alguém já te deu alguma indicação: "Ah, vai lá em tal lugar"; e você foi?

Dulcinéia - Não".

Ou seja, os seus contatos não parecem suficientes para fazê-la ingressar nesse nicho do mercado de trabalho. Por um lado, porque poucas são as pessoas do seu círculo de relações que têm ligação com a área de radiologia. Por outro lado, porque as demais pessoas com as quais estabelece vínculos são parte do mundo que ela quer abandonar, muito parecidas com ela do ponto de vista socioeconômico e, por isso mesmo, igualmente distantes do universo profissional ao qual quer aceder. Com efeito, nada menos que $63 \%$ das pessoas da sua rede moram no seu bairro ou em outras áreas periféricas da Zona Sul de São Paulo. Entre as demais, apenas duas, que a ela se vinculam pela esfera do trabalho, parecem ter um perfil socioeconômico distinto; mas, ainda assim, engajadas em atividades que em nada se articulam com as oportunidades que podem ser disponibilizadas na área de radiologia.

A configuração das esferas de sociabilidade tecidas por Dulcinéia ao redor do trabalho e do estudo é igualmente reveladora da sua dificuldade em manter vínculos que não tenham como base relações primárias, de vizinhança ou de família. A esfera trabalho é composta quase totalmente por contatos de seu emprego atual; são vínculos recentes e aparentemente instáveis, já que parecem 
REDES- Revista hispana para el análisis de redes sociales

Vol.22,\#6, Junio 2012

http://revista-redes.rediris.es

não participar tão intensamente do cotidiano da entrevistada. Já as esferas de sociabilidade construídas em suas experiências de estudo são exíguas em relações: em cada uma delas Dulcinéia indica a sobrevivência de apenas um contato formando a sua rede pessoal atual. Ou seja, aqueles vínculos que, a princípio, poderiam Ihe dar acesso a outros espaços de sociabilidade não se mantiveram.

Ao contrário, Dulcinéia mostra-se mais conectada àqueles com quem estabelece relações primárias, por vínculos familiares ou de vizinhança, as quais estão baseadas na proximidade física e na semelhança dos perfis socioeconômicos; com efeito, as esferas "família", "família de Sergipe", "amizade" e "vizinhança" conformam mais de $70 \%$ dos nós de sua rede. Mais ainda, aqueles contatos que the forneceram alguma "dica" de trabalho que deu certo pertenciam todos à sua esfera familiar.

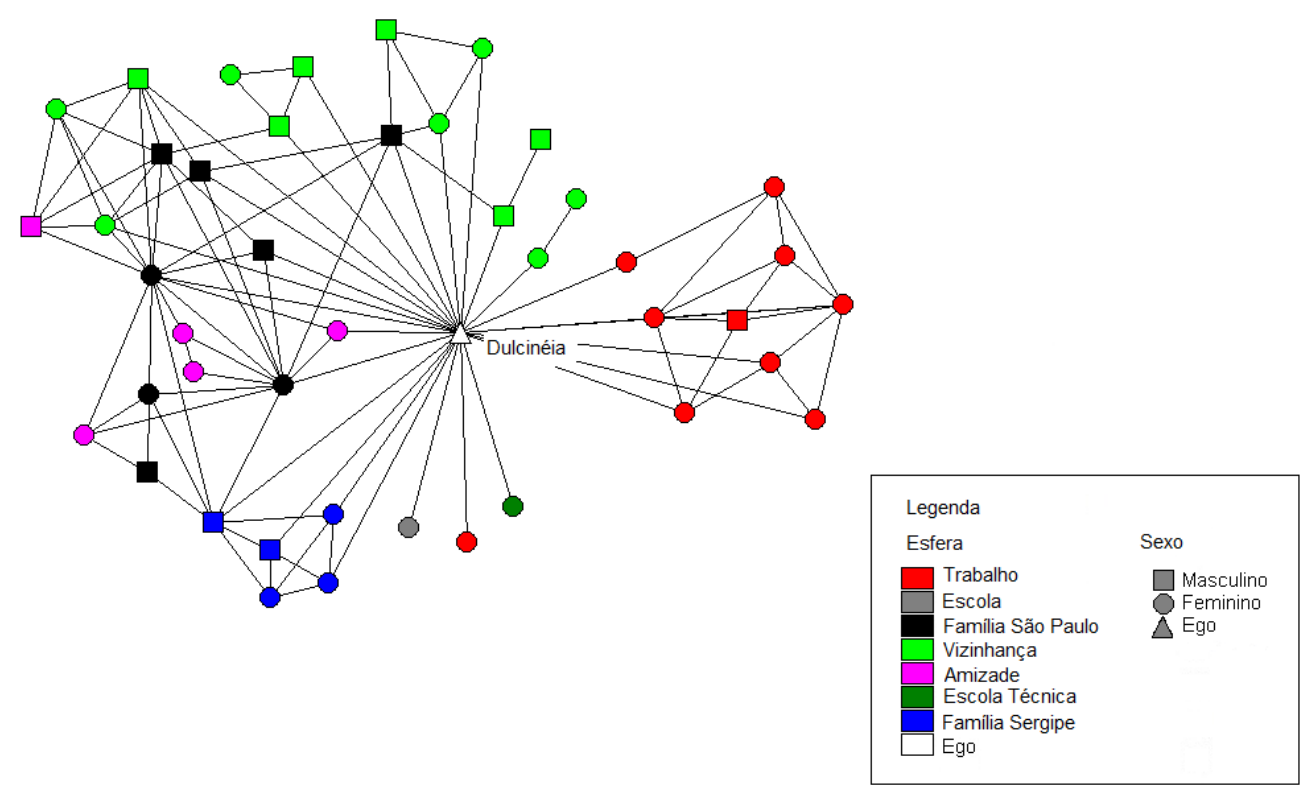

Gráfico 1. Sociograma da rede pessoal de Dulcinéia

Assim, se seus contatos pessoais Ihe descortinam novas chances de emprego, o tipo de oportunidade que produzem acaba por ajudar a retê-la em trabalhos de pouca qualificação, ligados à limpeza; e, sobretudo, distantes de seu objetivo, o de alcançar um emprego que a leve a exercitar sua competência em radiologia. Ou seja, os elos da sua rede pessoal não se configuram em ativos que, uma vez mobilizados, pudessem Ihe alçar no mercado de trabalho. 
REDES- Revista hispana para el análisis de redes sociales

Vol.22,\#6, Junio 2012

http://revista-redes.rediris.es

Do ponto de vista dos seus atributos, Dulcinéia parece reunir características que também contribuem para dificultar a almejada mobilidade social. Sua cor (parda) e a origem (nordestina) provavelmente pesam na balança das chances. E se é certo que, na longa entrevista, em nenhum momento experiências de discriminação vieram à baila, tema de resto silenciado pela maioria dos entrevistados, esses seus atributos a situam em dois dos grupos de mais alto risco com respeito ao reparto de oportunidades no mercado de trabalho paulistano, os negros e os nordestinos.

Mas há ainda outro passivo, relacionado à sua posição na família, que sem dúvida tem afetado, e negativamente, o desfecho da sua trajetória profissional. Dulcinéia é mãe solteira, e vive sozinha com um filho de 15 anos que ainda não começou a trabalhar. Ela tem consciência das dificuldades que enfrenta no mercado de trabalho e da vulnerabilidade que caracteriza a sua vida profissional, também marcada por sua condição de provedora da família:

"Eu queria ser qualquer coisa, menos onde eu "tô" hoje [auxiliar de limpeza]. Mas... - incrível! - continuo no mesmo lugar. Por isso que eu "tô" falando que eu não progredi muito. Quer dizer, eu só estudei, né?... me preparei, mas... Enfim, não sei se foi acomodação da minha parte. (...) Querendo ou não, uma pessoa sozinha, com filho... Você vai procurar ... às vezes ... eu via o salário do mercado, e ainda pagando aluguel, com filho, como eu ia fazer? E o único lugar que tirava um dinheirinho a mais era nesses lugares que eu fiquei [trabalhando como diarista e com trabalhos que pediam pouca qualificação]".

Embora ciente das dificuldades para a ascensão profissional, Dulcinéia persiste em sua busca por empregos de qualidade superior aos que obteve ao longo de sua trajetória de trabalho. Se seus contatos não podem prover indicações que lhe auxiliem nesse projeto de vida, é nos concursos públicos que Dulcinéia vê um meio possível de inserção no setor em que fez sua formação técnica.

"(...) tomo banho, tomo um cafezinho quente - com esse frio, Ave Maria! chama cafezinho quente, né? com leite. E fico lá, mulher... Aí, meu Deus, quando vejo já são 2 horas da manhã; e eu lá no computador! Fico lá fuçando, procurando os concursos que dá pra eu prestar, né?, que tá dentro da minha área e o que me interessa; porque não é só na área que eu faço concurso. (Grifos nossos)"

Dulcinéia se refere à radiologia como sendo "a sua área". Para ela, essa formação Ihe deu a possibilidade de se identificar com uma profissão e de se entender como fazendo parte de um segmento específico do mercado de trabalho. A representação de Dulcinéia sobre o que almeja para a sua vida profissional guarda estreita relação com "essa área" ocupacional, muito embora ela nunca tenha, de fato, obtido emprego em tal setor. Mesmo passados mais de cinco anos da conclusão de seu 
REDES- Revista hispana para el análisis de redes sociales

Vol.22,\#6, Junio 2012

http://revista-redes.rediris.es

curso técnico, Dulcinéia permanece buscando vagas nessa "sua área de atuação", a denotar como a maneira como construiu subjetivamente a sua identidade profissional por pouco efetiva que seja, segue guiando a sua conduta na procura por trabalho.

O seu modo de representar o mercado de trabalho se expressa, igualmente, no futuro que projeta para o seu filho, estudante do primeiro ano de ensino médio. Dulcinéia insiste para que o jovem conclua ao menos esse nível de ensino. Mas, para ela, não basta a formação escolar do filho. Quando a entrevistamos, ela já planejava conseguir-lhe uma vaga de emprego no local em que ela própria prestava serviço de limpeza. Almejava que seu filho não apenas investisse em sua formação escolar, mas que o fizesse pari passu com a sua inserção no mercado de trabalho. A vida profissional ansiada para o filho se articula, ademais, com seus próprios projetos de carreira. Isso porque, a seu juízo, a possibilidade de aperfeiçoar a sua formação em radiologia, que requereria o seu ingresso no ensino superior, será tanto mais remota quanto mais tempo ela permaneça como a única provedora de renda.

Dulcinéia tem clareza sobre o desafio que enfrenta (ascender profissionalmente), sobre a sua impotência face ao mesmo (transparente na sua incredulidade face ao resultado) e sobre aquele que entende ser o limite que se interpõe entre desejo e realidade (a condição de mãe solteira e provedora exclusiva). O resultado, para ela inaceitável (a mobilidade inalcançada e a permanência na vulnerabilidade), resulta do modo como se combinam os seus atributos, as suas representações sobre o mundo do trabalho e os traços que bem descrevem sua rede, a saber, a homofilia e o localismo.

Francisco, como Dulcinéia, tem uma trajetória de trabalho pouco segura. Isso os aproxima e nos fez incluí-lo nessa primeira configuração tipificada por Dulcinéia. Igualmente pardo, migrante e nordestino, aos 20 anos Francisco deixou a Bahia rumo a São Paulo ${ }^{17}$. Desde então - e o entrevistado tinha 30 anos quando o reencontramos - Francisco permaneceu prisioneiro de um setor, o da construção civil, apesar de ter realizado uma série de cursos técnicos em áreas tão distintas quanto treinamento para porteiro, informática, montagem e manutenção de computadores ou marketing.

\footnotetext{
17 Francisco migrou inicialmente para Praia Grande, litoral do Estado de São Paulo. Sua migração e posterior entrada no mercado de trabalho foram auxiliadas por um irmão que havia se transferido anteriormente para aquela cidade.
} 
REDES- Revista hispana para el análisis de redes sociales

Vol.22,\#6, Junio 2012

http://revista-redes.rediris.es

Francisco conseguiu todos os seus trabalhos no setor por meio de contatos da sua rede. Curiosamente, ao longo de toda a sua entrevista, inexiste um discurso sobre o modo como os procurava e nem como os obtinha. Pelo contrário, para Francisco, parece que bastaria tomar a decisão de procurar trabalho e conseguiria algum posto na construção civil. Ele destaca, por exemplo, que, em sua trajetória neste setor, raramente viveu intervalos de tempo em que se visse à procura de trabalho, entre um serviço e outro; ao contrário, por vezes serviços diferentes até se sobrepunham. Ademais, a cada momento em que Francisco tentava exercer outras ocupações - por exemplo, quando foi garçom por um período de seis meses - a construção civil permanecia como o seu espaço de garantia de renda, para o qual sabia poder voltar se não obtivesse aquilo que desejava por meio do seu novo emprego.

Entretanto, se a sua rede de contatos é o meio por excelência para a obtenção de seus trabalhos na construção civil, é curioso notar que, quando busca empregos em outras áreas, Francisco faz uso preferencial de outros mecanismos de procura, como os anúncios de jornal e, sobretudo, as agências de emprego. Esses, entretanto, não parecem lhe haver brindado com bons resultados; isso porque poucos foram os empregos para os quais Francisco foi chamado e a todos eles recusou, visto o baixo salário oferecido, incapaz de compensar a renda obtida como autônomo na construção civil.

"Entrevistadora: (...) você falou que procurou bastante em agência. Como foi essa tua experiência nas agências? como que você fazia? como você ficou sabendo?

Francisco: Jornais, né? a gente vai no jornal, às vezes alguém vai procura e fala: "Ah, tal empresa tá pegando". Aí "cê" vai... Teve um que eu fui na agência de Itapevi e fiz uma prova; passei, fiz teste na empresa, mas quando ia falar em salário, né, é muito baixo!"

A rede de Francisco tem 33 contatos, ou seja, é uma rede média se comparada aos demais casos. Mas é uma rede relativamente mais densa $(0,1747)$, com 196 vínculos entre os nós. Marcante homofilia de gênero: mais de $80 \%$ da rede é composta por contatos do sexo masculino. Quando observamos as suas seis esferas de sociabilidade, percebemos uma sobreposição significativa entre os contatos que se estabeleceram em sua esfera de trabalho - composta, sobretudo, por colegas da construção civil - e aqueles constantes da sua esfera de vizinhança - composta por migrantes, seus conterrâneos. Ou seja, a homofilia de gênero parece estar ligada à homofilia com respeito a outras características sociais dos nós que formam a sua rede; eles não somente são homens, mas são também trabalhadores da construção 
REDES- Revista hispana para el análisis de redes sociales

Vol.22,\#6, Junio 2012

http://revista-redes.rediris.es

civil, são seus vizinhos e seus conterrâneos (ou filhos de conterrâneos). Não por acaso, é das esferas trabalho e vizinhança que Francisco obtém informações e dicas sobre empregos na construção civil. Mais notável ainda: não há contato registrado na sua esfera de trabalho que já não Ihe tenha fornecido esse mesmo tipo de ajuda.

Tal como Dulcinéia, esses contatos homofílicos the proporcionaram os múltiplos trabalhos temporários, que Ihe garantiram renda. ${ }^{18}$ Entretanto, por serem vínculos com indivíduos socialmente muito similares, eles não the permitiram acesso a outras oportunidades de emprego que the propiciassem a ascensão social esperada, dados o seu investimento em qualificação profissional e a sua busca sistemática através de agentes do mercado (anúncios de jornais ou agências).
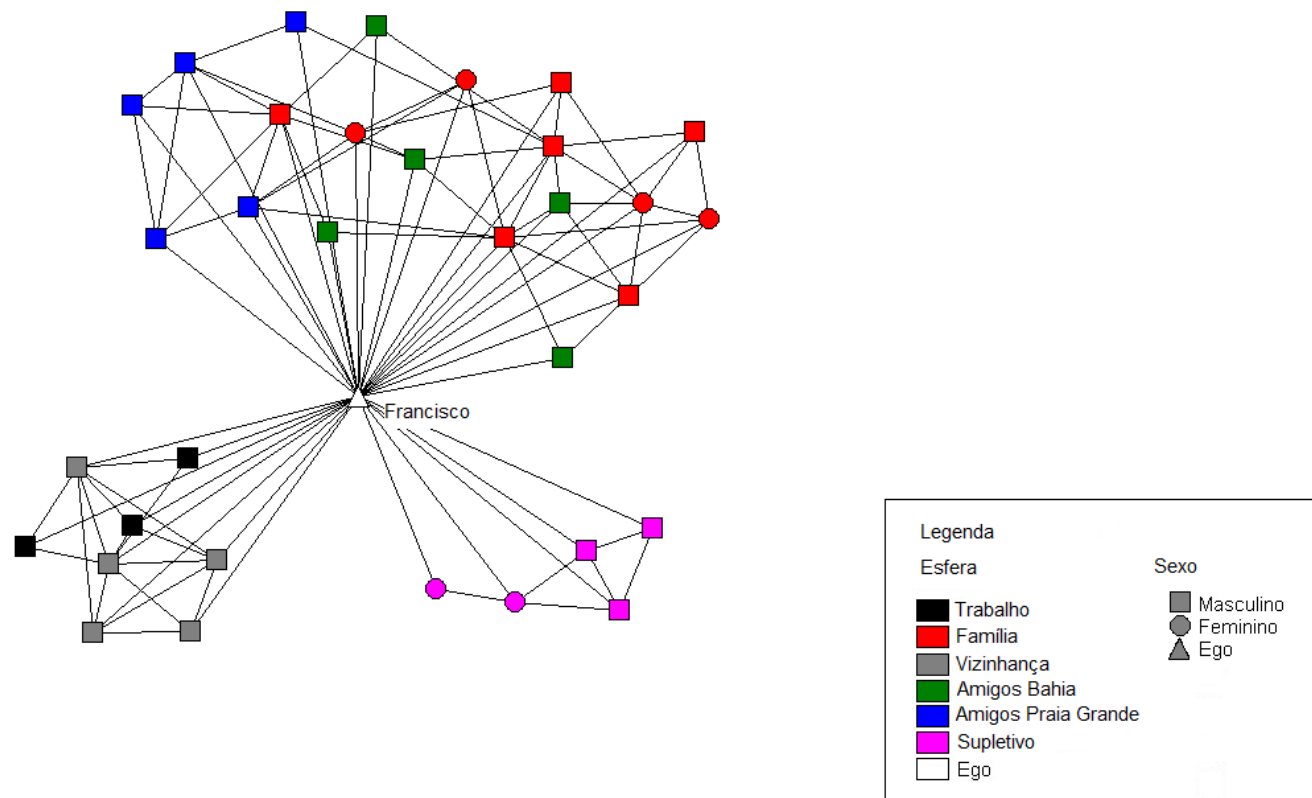

Gráfico 2. Sociograma da rede pessoal de Francisco

Por outro lado, ainda que a estrutura da rede de Francisco pareça ser mais desfavorável que a de Dulcinéia - por ser menor e mais densa, além de mais homofílica socialmente (logo com maior probabilidade de redundância de informação) -, não deixa de ser curioso que ela tenha Ihe propiciado uma trajetória

18 Os laços de Francisco com os contatos de sua esfera de trabalho são caracterizados pela reciprocidade. Uma vez que juntos eles formam uma espécie de equipe de trabalho de construção civil, as indicações circulam entre eles em várias direções. São indicações que valem tanto para trabalhos a serem exercidos conjuntamente, como para serviços que, por não poderem ser realizados por aquele que recebeu a informação, são repassados a outros colegas da equipe. 
REDES- Revista hispana para el análisis de redes sociales

Vol.22,\#6, Junio 2012

http://revista-redes.rediris.es

ocupacional mais segura. Francisco esteve, por exemplo, menos sujeito a períodos de desemprego que Dulcinéia; a sua rede era capaz de gerar informações regulares sobre trabalho na construção civil (afinal, um mundo de homens e de migrantes!), mesmo se nada efetiva para a sua mobilidade social. Apesar disso, pôde sobreviver a partir desses trabalhos (mesmo se indesejados). Mas há um outro dado significativo: Francisco é solteiro, não tem filhos e vive só; ou seja, os seus cálculos no mercado de trabalho estão livres dos constrangimentos que Dulcinéia destacara acima.

Se contrapusermos o caso de Francisco ao de Vanda, outra de nossas entrevistadas a ter tido uma inserção mais insegura no mercado de trabalho, é possível explorar novos modos pelos quais atributos individuais e eventos da trajetória de vida podem se relacionar às trajetórias profissionais. Vejamos em seguida.

Vanda tinha 39 anos no momento em que a reencontramos para a entrevista. Parda, nasceu em São Paulo, onde concluiu o ensino médio em um curso supletivo. Nos quatro anos anteriores à entrevista havia feito uma série de cursos técnicos, dentre os quais os de cabeleireiro e informática. Estava separada e vivia com seus dois filhos jovens. O mais velho deles trabalhava, mas seu salário era utilizado para financiar sua própria formação. A rede de Vanda tem 26 contatos e 106 vínculos. É, portanto, não apenas menor, mas menos densa $(0,151)$ que a de Francisco. Mas é igualmente homofílica em termos do sexo e da localização de seus contatos quase $70 \%$ dela é composta por mulheres e $92,3 \%$ dos nós da rede vive num raio de cerca de quatro quilômetros do seu local de moradia. ${ }^{19}$

\footnotetext{
19 Como se verá ao longo da análise, o localismo é um tipo de homofilia social que se revelou um importante mecanismo para se entender o modo como se estabelecem, nesse grupo de entrevistados, os elos entre atributos, relações e oportunidades no mercado. Por entendemos o localismo como um indicador poderoso de homofilia social, procuramos caracterizá-lo indo além da identificação de um mesmo espaço geográfico onde tem lugar a interação entre ego e seus contatos; também consideramos as falas dos entrevistados sobre o modo de vida desses contatos, traço igualmente relevante para caracterizar a homofilia social que subjace ao localismo.
} 
REDES- Revista hispana para el análisis de redes sociales

Vol.22,\#6, Junio 2012

http://revista-redes.rediris.es
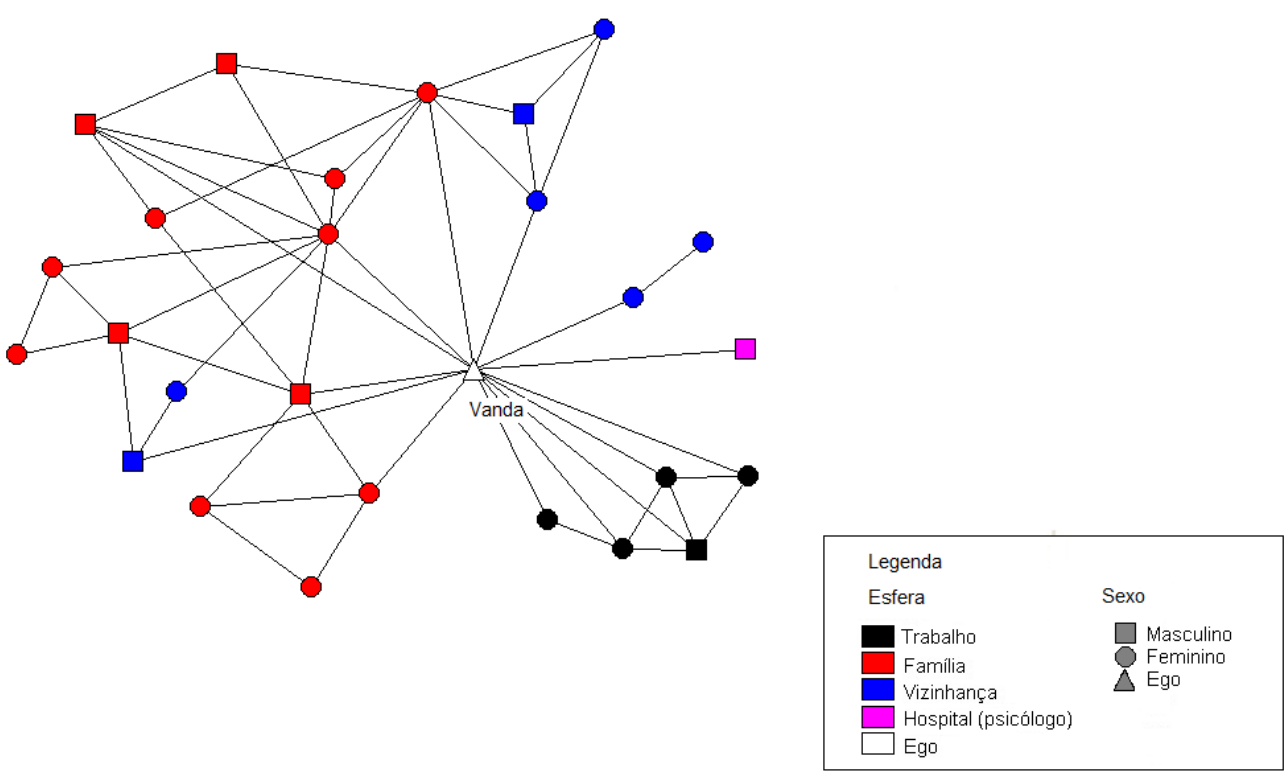

Gráfico 3. Sociograma da rede pessoal de Vanda

Diferentemente do caso de Francisco, em que homofilia e localismo não impediram a sua rede de lhe prover abundantes informações sobre trabalho, no caso de Vanda inexiste tal virtuosidade. Mais ainda, Vanda é o único caso, dentre os que trataremos, em que as redes não são o mecanismo mais freqüente de obtenção de trabalho. Dos 14 empregos assalariados que compõem o seu percurso ocupacional, apenas três foram obtidos a partir de informações provindas de seus contatos, mais especificamente de familiares ou vizinhos bastante próximos de sua família. Para Vanda, as redes não são o mecanismo usual na sua busca por trabalho. Como Francisco, é por meios mercantis que costuma procurar emprego; mas, diferentemente dele, Vanda consegue empregos fazendo uso desses meios. Mais da metade das suas 14 ocupações foi obtida por mecanismos mercantis e sem apoio em redes de contatos pessoais: três por meio de agências de emprego, duas por anúncio, duas outras por prospecção direta e uma por concurso ${ }^{20}$.

Francisco e Vanda fazem largo uso de mecanismos mercantis e, mesmo se de modo não intencionado, procuram escapar das limitações de suas redes. Curioso, entretanto, o fato de que Francisco (mesmo tendo investido em sua formação

\footnotetext{
${ }^{20}$ Em sua trajetória ocupacional, Vanda trabalhou em negócio próprio em três momentos diferentes.
} 
REDES- Revista hispana para el análisis de redes sociales

Vol.22,\#6, Junio 2012

http://revista-redes.rediris.es

técnica, complementarmente à busca mercantil) não obtenha o mesmo tipo de resultado que Vanda. Terão os atributos individuais algum papel explicativo?

Com efeito, Francisco demonstrou na entrevista não dominar os códigos de conduta exigidos dos que buscam trabalho por meios mercantis, como é o caso das agências de emprego. Revelou timidez, dificuldade em articular suas idéias e uma narrativa plena de erros gramaticais. Sabemos, por outros estudos (Vieira, 2009; Guimarães, 2009), que essas características o distanciam do padrão do "bom demandante de trabalho", tal como entendem as selecionadoras no mercado de intermediação; ou seja, o modo como se apresenta nesse tipo de situação não o auxilia a obter os trabalhos com a qualidade que almeja.

Mas pesa a favor de Francisco o fato de que ele sempre conseguia serviços no setor de construção civil e, deste modo, podia abrir mão de empregos que não the remunerassem tão bem. Já Vanda não teve esse suporte. Pior: ela tem filhos para cuidar, enquanto Francisco era um provedor apenas para si mesmo. Trata-se, afinal, de um caso em que a posição na família e os próprios eventos do ciclo de vida tiveram impacto importante na regularidade das trajetórias de trabalho. Vanda teve dois filhos e deixou o mercado de trabalho nas duas vezes em que engravidou, retomando a busca por emprego apenas quando os filhos tinham entre dois e três anos de idade. Voltou a deixar o mercado para cuidar do irmão, quando este se recuperava de um acidente. Sua trajetória - de resto, convergente, pelos acidentes que a fazem fragmentária, com o tipo "feminino" de percurso no mercado de trabalho - é entremeada por interrupções diversas, sempre devidas a eventos familiares, que contribuíram não apenas para a sua inserção ocupacional desfavorável, como também para a dificuldade de manutenção dos vínculos construídos nas esferas profissionais.

Todavia, há mulheres e mulheres. Vale dizer, tipificar um percurso como "feminino" não deve eludir a diversidade no modo de confrontar os desafios que os papeis sociais de gênero impõem. Assim, se comparamos as biografias de Vanda e Dulcinéia, vemos que elas são distintas em relação à eficácia do suporte propiciado pela esfera familiar das suas redes. No caso de Dulcinéia, ainda que ela seja mãe solteira e tenha criado sozinha seu filho, ela pode contar com o apoio de sua família, principalmente de suas irmãs, o que lhe permitiu, por exemplo, continuar investindo em sua formação profissional. As irmãs cuidavam de seu filho enquanto ela se dedicava a estudar. Além disso, a família tem Ihe prestado apoio na vida profissional; muitos dos seus trabalhos foram obtidos a partir de "dicas" dadas por familiares. 
REDES- Revista hispana para el análisis de redes sociales

Vol.22,\#6, Junio 2012

http://revista-redes.rediris.es

Vanda, pelo contrário, não apenas prescinde de apoio familiar no cotidiano, como é ela quem presta esse tipo de ajuda à família. Nesse sentido, antes que uma rede de apoio, sua família parece operar como um dique de contenção, retendo Vanda na esfera doméstica. Ademais, as características do bairro em que vive parecem também estar associadas às diferenças que encontramos em relação a Dulcinéia. Socialmente vulnerável e, sobretudo, bastante violento, o seu entorno lhe deixou, em vários momentos de sua vida, marcas indeléveis: seu pai foi assassinado, quando ela ainda era adolescente, e seu irmão havia sido baleado, também naquela região.

Mas, Vanda e Dulcinéia se diferenciam também no modo como prospectam o mercado de trabalho. Dulcinéia, como vimos, tem uma procura de trabalho direcionada; ela busca empregos na área com a qual se identifica profissionalmente, mesmo se não tenha tido bem sucedida nessa busca específica. Vanda, ao contrario, parece não guiar sua conduta por uma lógica profissionalmente orientada: basta um emprego que the permita garantir 0 sustento da família, que the pesa sobre os ombros.

Deise é a mais jovem dentre os quatro casos ilustrativos dessa primeira configuração; completara 27 anos no momento da entrevista. Negra, estava casada e tinha uma filha. Nasceu em Guarulhos, cidade da Região Metropolitana de São Paulo, em cuja periferia ainda vive. Finalizou o curso médio, e havia também investido em vários cursos profissionalizantes (informática, mecânica e manicure). 

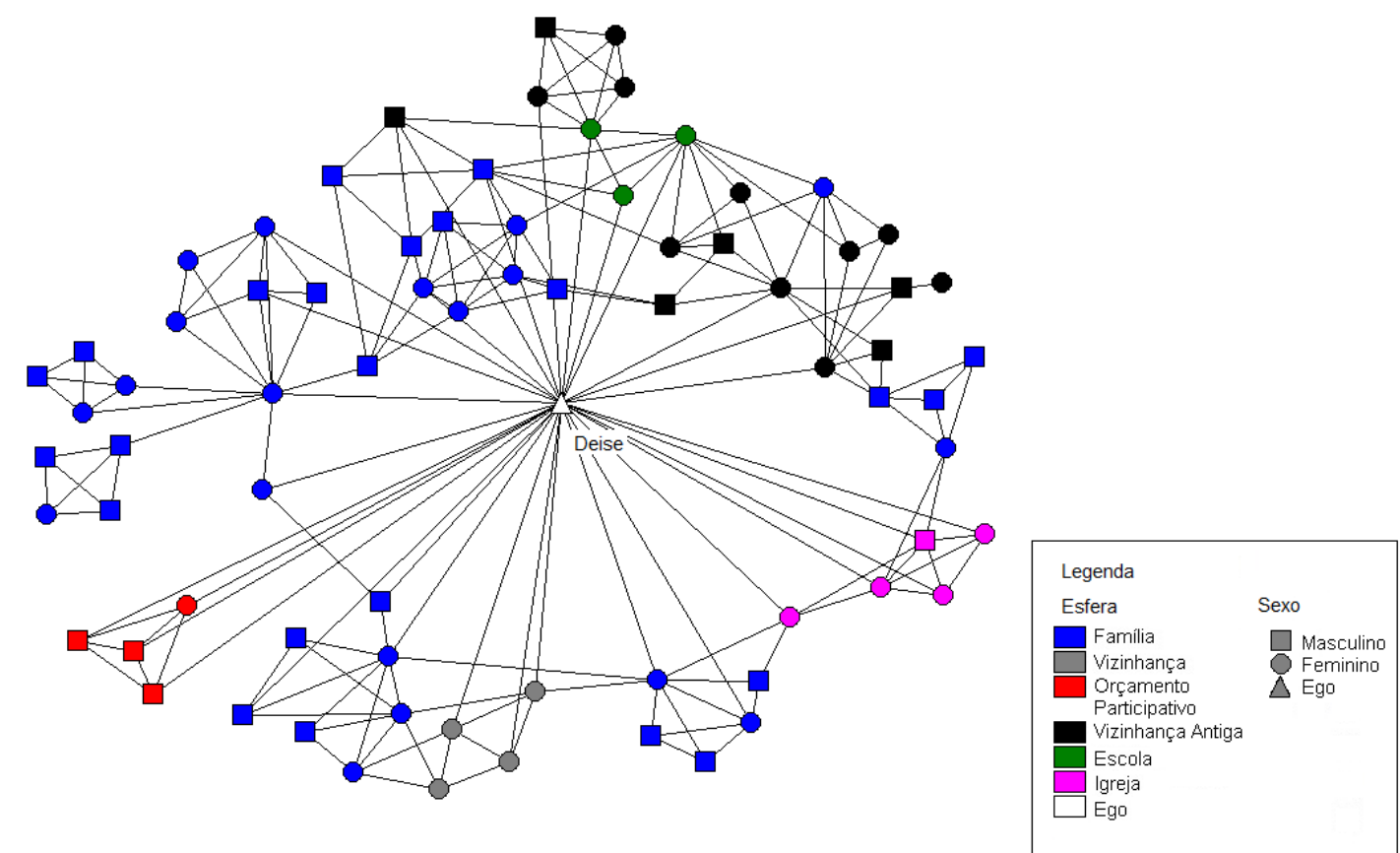

Gráfico 4. Sociograma da rede pessoal de Deise

A sua rede é significativamente maior face aos casos dessa primeira configuração (74 contatos e 376 vínculos), com menor homofilia de gênero e menor densidade $(0,0677)$. Essas características poderiam sugerir a um intérprete mais apressado uma provável diversidade dos circuitos de informação de Deise e, por conseqüência, maior riqueza de informações a circular na rede. Entretanto, não é isso que ocorre. Evidencia disto: ela estava desempregada no momento da entrevista. E por que? Aí reside o interesse em agregarmos, com esse caso, uma nova variante para essa primeira configuração. Vejamos.

Há uma forte ligação entre os contatos que resultavam, por um lado, de suas relações na escola e, por outro, das suas interações com seus familiares e antigos vizinhos, a indicar quão circunscritos e superpostos eram os vínculos existentes entre as três esferas nas quais Deise tecia suas relações. Com efeito, trata-se de uma rede caracterizada pelo localismo; quase $80 \%$ dos contatos mora em seu bairro ou no bairro vizinho. Bairros socialmente periféricos, vulneráveis e com muito menor acesso a serviços. Nesse sentido, o localismo limita a entrevistada a informações concentradas em um mesmo espaço geográfico, funcionando como um passivo, em suas tentativas de ultrapassar, pela via do trabalho, a sua situação atual; vendo-o por um outro prisma, a homofilia social que anda de braços com o localismo, diminui as chances de Vanda vir a obter, pela via da sua rede, as informações que Ihe possibilitem a mobilidade ocupacional. 
REDES- Revista hispana para el análisis de redes sociales

Vol.22,\#6, Junio 2012

http://revista-redes.rediris.es

Em outros casos já apresentados (Vanda, Francisco e Dulcinéia) também reconhecemos um efeito de homofilia social latente na conformação da rede; e em todos eles vimos que as possibilidades de ascensão social eram menores. Entretanto, eles diferem de Deise na medida em que são casos em que a procura de trabalho é bastante expressiva, estando fortemente presente na narrativa sobre a vida cotidiana e, nesse sentido, como orientador da conduta do entrevistado. Deise, ao contrario, não atribui à procura de trabalho um estatuto central em seu discurso sobre as iniciativas de reinserção. Isso ficou claro já na pergunta que abria a entrevista:

"Entrevistadora - ... eu queria que você falasse pra gente, de 2004 até agora, como foi a sua experiência?

Deise - De trabalho?

Entrevistadora - Isso.

Deise - De 2004 pra cá eu trabalhei só numa loja, e, assim, não saí pra procurar serviço, não trabalhei fora não, só em casa mesmo. (Grifos nossos)"

Na sua primeira frase já transparece o peso dos eventos da vida privada. Família, casamento e maternidade marcam a sua biografia, a sua trajetória ocupacional e a configuração da sua rede. Deise mora em Guarulhos desde seu nascimento, vivendo hoje com o marido e a filha pequena; quando casou, mudou-se para o bairro vizinho àquele onde residiu por toda a vida. Na sua narrativa biográfica destacam-se os seus papéis de mãe e dona de casa, o que não só a faz estar voltada "para a casa", mas reforça a predominância das esferas primárias de sociabilidade, como a família e as vizinhanças, antiga e atual. A força avassaladora desses papéis na organização da sua vida explica o fato de que seja a única, dentre os casos selecionados, cuja rede pessoal carece de uma esfera de sociabilidade resultante da sua inserção (mesmo se frágil e/ou eventual) no mundo do trabalho. Não sem razão, Deise só procura trabalho em momentos de desemprego do marido, e tem como único recurso para fazê-lo a sua investida, individual e isolada, junto aos possíveis empregadores; nem redes e nem instituições do mercado estão presentes secundando essas incursões episódicas.

Apesar de sua procura acontecer nos períodos em que seu marido está desempregado, isso não significa que Deise prescinda de uma fonte alternativa de renda. A sua principal ocupação, de 2000 em diante, foi o trabalho como bordadeira. Ela foi introduzida a essa atividade por meio de sua cunhada. Trata-se de um trabalho passível de ser exercido em domicílio, coadjuvando a sua rotina de 
REDES- Revista hispana para el análisis de redes sociales

Vol.22,\#6, Junio 2012

http://revista-redes.rediris.es

afazeres domésticos. Feito em casa, o bordado é, em seguida, levado à pessoa responsável por entregar o produto à empresa contratante. Cada bordadeira recebe por peça produzida. São trabalhos esporádicos, "bicos", que a entrevistada faz de acordo com as necessidades financeiras da família.

Por ser realizada em casa, essa ocupação reforça o insulamento de Deise no espaço domiciliar e na esfera familiar, dificultando a formação de vínculos entre as bordadeiras e mesmo o seu próprio reconhecimento de que haja uma esfera de sociabilidade que resulte da sua (mesmo se esporádica e isolada) experiência de trabalho, conquanto se saiba que a realização desse seu bico requer o mínimo estabelecimento de contatos; mas Deise não os reconhece como existentes no seu mundo relacional. Assim, embora a rede de Deise não Ihe proveja com informações nos momentos em que ela decide sair do ambiente doméstico para procurar trabalho, ela é central para a manutenção da renda familiar, obtida com o bordado.

A força desse cotidiano de eventos familiares é notável; é ele que organiza o tempo da narrativa de Deise. Assim, o início do bordado tem como marca temporal o "antes de eu ter a minha filha"; e a busca por bordados está ligada ao maior ou menor "relaxamento" no curso da vida, reflexo da presença (ou ausência) de trabalho na vida do marido. Veja-se o trecho abaixo:

"Deise - O bordado é assim: você pega quando você quer pegar, né? Não é uma coisa, assim, que precisa seguir regras. Se você quer pegar, você pega; se não quiser, você não pega.

Entrevistadora - E desde quando que você borda, você lembra?

Deise - Acho que 2000, antes de eu ter a minha filha eu já bordava.

Entrevistador - E aí, vira e mexe, você pega alguma coisa?

Deise - É.

Entrevistador - Desde 2000 pra cá?

Deise - É. Pego, assim, quando tá precisando de mais dinheiro; aí a gente borda mais. Quando tá mais sossegado, que nem agora, o meu marido ficou desempregado no mês passado, daí preciso bordar mais. Aí quando ele arruma um serviço, eu fico mais relaxada, não precisa bordar tanto. (Grifos nossos)"

Deise parece ter optado por ser dona de casa e não atuar no mercado de trabalho. Difere de Vanda, para quem os eventos familiares também influenciam a trajetória ocupacional, mas em cujo discurso a procura tem lugar destacado. Na narrativa de Deise, ao contrario, a busca por trabalho e a construção de uma trajetória profissional não são prioridades; e não sem razão, pelo visto acima. 
REDES- Revista hispana para el análisis de redes sociales

Vol.22,\#6, Junio 2012

http://revista-redes.rediris.es

Tomados como um conjunto, esses quatro primeiros trajetos ocupacionais confluem para um mesmo resultado, o da inserção precária no mercado de trabalho. E usamos precária num duplo sentido. Por um lado, porque os vínculos que estabelecem são efetivamente inseguros, seja por sua instabilidade, seja pelo escasso rendimento que provêm. Por outro lado, porque eles são percebidos como precários, seja porque não facultam ao entrevistado exercer a ocupação almejada (e para a qual crê haver-se preparado), seja porque não lhe permitem fazer face aos compromissos e papéis sociais correlatos à sua condição geracional, ou à sua posição no grupo familiar.

Mas, para além de uma inserção precária no mercado de trabalho, existirão outros traços em comum entre esses casos? Diríamos que sim. No que diz respeito aos seus atributos individuais, observamos que todos os quatro entrevistados são negros (pardos ou pretos). Além disso, todos eles, ao longo de sua trajetória ocupacional, investiram em sua própria formação, sobretudo por meio da freqüência a cursos técnicos. Apesar disso, entretanto, nenhum deles tinha, no momento da entrevista, obtido ocupação na área de formação escolhida. Já no que diz respeito às características das redes desses indivíduos, há que se destacar a presença freqüente de contatos de esferas primárias, notadamente a família e a vizinhança.

Mas, se a inserção precária no mercado de trabalho é o principal resultado convergente, o modo como se chega a esse resultado convergente varia conforme o caso. Cada um deles figura um arranjo entre efeitos de atributos e efeitos de relações, operantes e representados, ambos, de maneira particular, ao longo de cada biografia individual. Mais ainda, cada um deles mostra que são as nuances ou os aspectos particulares relativos seja aos atributos, seja à natureza da rede, os mecanismos eficientes que, uma vez enlaçados no curso de suas práticas e ancorados em suas representações, estabelecem os graus de liberdade dentro dos quais está o resultado a ser alcançado por cada um deles no mercado de trabalho.

Mas, o que os diferencia? Qual o lugar desses aspectos distintivos no processo que resultou na precária inserção que caracterizava a situação ocupacional no momento em que os reencontramos? Como atributos e relações se enlaçam de formas diferentes, nas práticas e representações desses entrevistados?

Deise, por exemplo, se destaca por ter uma estrutura de rede bastante diferente dos demais casos, ao menos no que diz respeito ao número de nós que a constitui. Enquanto os outros três casos têm 43, 33 e 26 contatos, a rede de Deise tem 74 . 
REDES- Revista hispana para el análisis de redes sociales

Vol.22,\#6, Junio 2012

http://revista-redes.rediris.es

Ainda que relativamente grande, sua rede é bastante marcada pela presença de nós provenientes de esferas mais ligadas à sua vida doméstica. Assim, se pudéssemos em poucas linhas descrever a importância da estrutura da rede neste caso, poderíamos dizer que, apesar de grande, é uma rede pouco diversificada no que diz respeito às características dos contatos que a constituem. Vale dizer, o tamanho da rede de Deise não nos ajuda a entender a sua situação ocupacional atual. Há, ainda, outra característica central da entrevistada que nos permite compreender melhor a ineficácia de sua rede no que diz respeito ao trabalho. Diferentemente dos três outros casos a esfera de trabalho tem, para Deise, reduzida importância em sua vida. Talvez por isso mesmo, ela pareça muito menos insatisfeita com sua situação ocupacional.

Vanda, como Deise, é mãe; mas, diferentemente desta última, não conta com o apoio de um cônjuge na manutenção da casa. Além disso, tem uma rede significativamente menor (26 contatos), que pouco the serviu na obtenção de trabalhos. Talvez não por acaso, Vanda dê mais importância aos mecanismos mercantis de procura. Neste caso, sua posição na família combina-se com uma rede que não pode Ihe fornecer apoio, seja no que diz respeito à difusão de informações sobre trabalho, seja no que se refere a apoio relacionados a problemas cotidianos, configurando-se como o caso de maior vulnerabilidade ocupacional e social dentre aqueles que formam essa primeira configuração.

Já a rede de Dulcinéia, também pequena (43 nós), mostra-se mais profícua que a de Vanda, ao menos no que diz respeito à obtenção de trabalhos que exigem pouca qualificação. Para as aspirações de Dulcinéia, entretanto, sua rede não tem impacto positivo. A entrevistada havia investido em formação e pretendia obter um trabalho de maior qualidade, na área que escolhera; mas os contatos de sua rede não puderam, e não podem, ajudá-la. Há informações sobre trabalho circulando entre seus contatos, mas são informações que a mantêm na área da qual quer sair, a da limpeza. A primeira vista esse poderia ser um caso a documentar como não bastam o investimento em qualificação e a motivação para ascender socialmente por meio da inserção ocupacional de melhor qualidade; mas também pode ser visto como um caso em que tampouco a eficácia da rede de contatos pessoais no sentido de prover empregos a faz virtuosa aos olhos de ego. Aqui fica transparente a força do sentido conferido ao trabalho, à procura, à eficácia das redes: nada atende às expectativas e projetos de Dulcinéia se não a leva ao emprego "na sua área"; e até mesmo a inserção ocupacional do filho, tão logo obtenha o seu primeiro "diploma" é vista por ela como um meio na consecução da "trajetória imaginada" , bastante 
REDES- Revista hispana para el análisis de redes sociales

Vol.22,\#6, Junio 2012

http://revista-redes.rediris.es

diversa daquela "efetivamente trilhada", mas nem por isso menos importante em sua vigência simbólica.

Por fim, temos o caso de Francisco. Como Dulcinéia, Francisco investe em qualificação e, como ela, sua rede pessoal não lhe traz oportunidades de trabalho em qualquer das áreas em que se qualificou. A rede de Francisco é profícua no que diz respeito a informações de trabalho, mas, como no caso de Dulcinéia, são informações que o mantém exercendo sempre o mesmo tipo de atividade na construção civil. Francisco tenta mudar de área, mas o que obtém fora da construção civil fica sempre aquém daquilo que ganha mantendo-se nesse setor. Diferentemente dos dois últimos casos, Francisco é solteiro e não tem filhos e pode, portanto, arriscar seu trabalho na construção civil para tentar obter empregos em outras áreas. A posição de Francisco na família Ihe dá mais liberdade no que diz respeito à sua trajetória ocupacional, mas a rede - pobre em informações de trabalho de setores outros que a construção civil -, combinada à dificuldade de fazer uso de mecanismos mercantis de busca, tornam-se centrais para entender sua inserção precária no mercado de trabalho.

$\mathrm{Na}$ seção seguinte exercitaremos esse mesmo olhar analítico para recuperar nuances no que concerne a trajetórias que levam a outro desfecho, qual seja, o da obtenção do trabalho relativamente estável, com maior qualidade visto o rendimento que propicia, e mais próximo daquilo que fora subjetivamente almejado.

Como ponto de partida, tomaremos novamente um caso-chave, o de Sandra. Em seguida, procuraremos nuançar os modos de relação entre trajetórias, atributos e redes, lançando mão de três outros casos, confluentes pelo seu resultado, mas variantes no modo de articular os mecanismos que propiciaram tal desfecho: Elisabete, Rogério e Damaris. Para bem entender por que consideramos Dulcinéia, nesta sessão, e Sandra, na subsequente como configurações típicas, iniciaremos a apresentação do novo caso-chave (Sandra), explorando o que a aproxima e o que a diferencia do caso-chave anterior (Dulcinéia).

\section{A produção da (relativa) estabilidade: os modos de articular atributos e relações em (outros) quatro contextos biográficos. Sandra, Elisabete, Rogério, Damaris}

"Hoje em dia emprego é "QI", emprego "QI" é "Quem Indica".

A maioria dos meus empregos é "quem indicou" (Sandra). 
REDES- Revista hispana para el análisis de redes sociales

Vol.22,\#6, Junio 2012

http://revista-redes.rediris.es

Sandra, negra, tinha 28 anos no momento da entrevista. Nasceu em São Paulo, onde vive com sua irmã e uma sobrinha. Solteira e sem filhos, havia terminado o ensino médio e feito um curso de formação para manicures.

Sandra e Dulcinéia, antecipamos na seção de abertura deste texto, têm estruturas de rede bastante semelhantes: cerca de 45 contatos e densidades quase idênticas. A primeira tem oito esferas em sua rede e a segunda, sete. Essas redes também não se distinguem grandemente pela homofilia de sexo existente entre os seus respectivos contatos $(57,78 \%$ e $65,12 \%$, respectivamente). Entretanto, a rede de Sandra é bem menos local que a de Dulcinéia (28,89\% dos seus contatos vivem no mesmo bairro que ela, contra $51,16 \%$ no caso de Dulcinéia). Afora isso, três outros traços as diferenciam fortemente: as características dos indivíduos que compõem cada uma das redes; o modo como as esferas de sociabilidade foram formadas (e mantidas) ao longo do tempo; e, finalmente, a maneira como cada uma dessas entrevistadas diz mobilizar a sua rede de contatos.

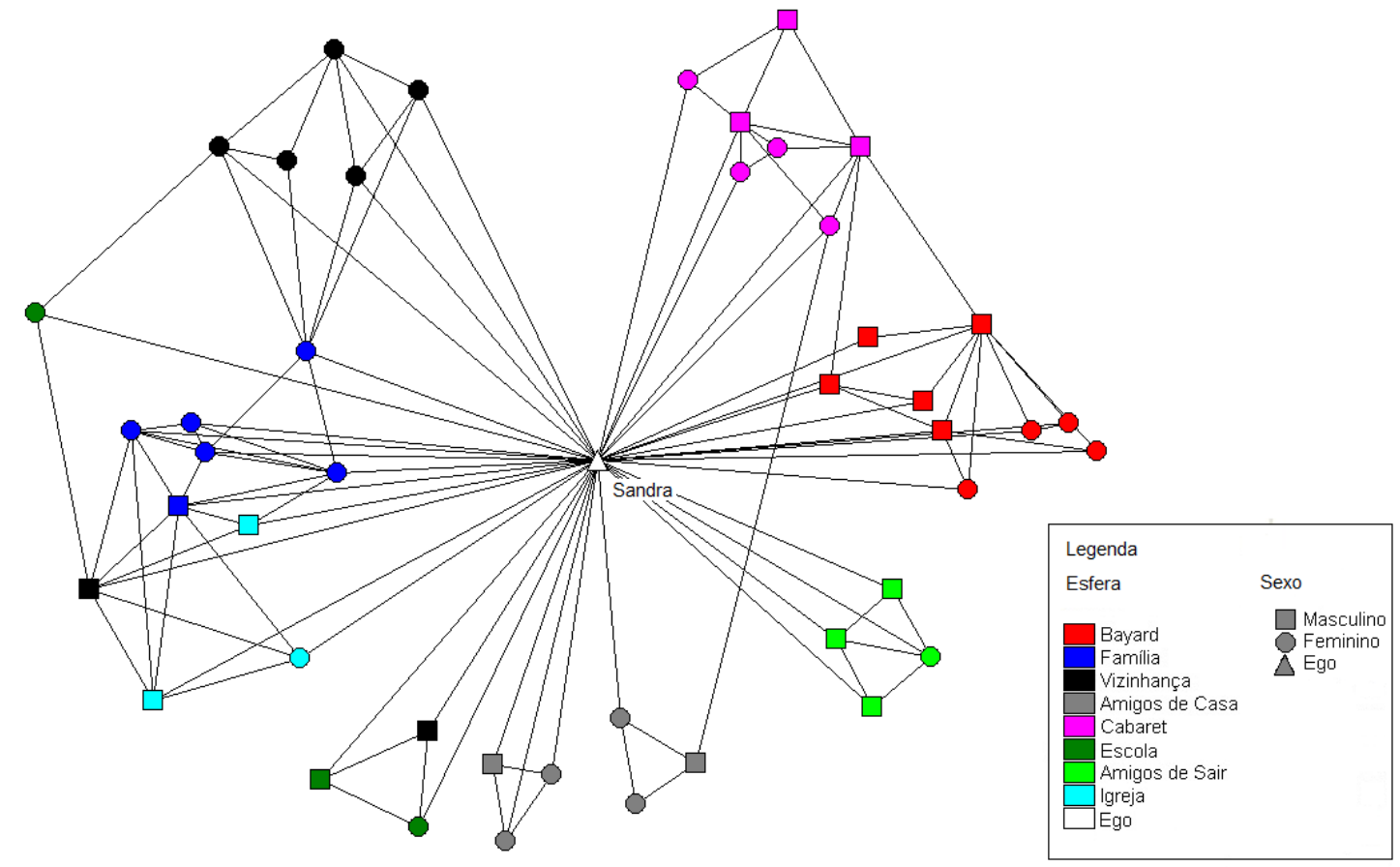

Gráfico 5. Sociograma da rede pessoal de Sandra

Diferentemente de Dulcinéia, Sandra parece ter mantido os vínculos criados em seus ambientes anteriores de trabalho. Mais interessante ainda: eles fazem parte não apenas do grupo de pessoas que ela classifica como sendo contatos tecidos nas suas esferas de trabalho, mas são incluídos entre os contatos que compõem outras esferas de sociabilidade, como as que denomina como a dos "Amigos de Sair" e a 
REDES- Revista hispana para el análisis de redes sociales

Vol.22,\#6, Junio 2012

http://revista-redes.rediris.es

dos "Amigos de Casa". Ou seja, mesmo essas duas esferas que não são representadas como "de trabalho", são formadas por contatos feitos em seus ambientes profissionais, atuais ou pretéritos. É como se os contatos seguissem sendo cultivados e fossem, por isso mesmo, re-significados, passando a formar parte de esferas marcadas pela interação mais estreita e privada.

No momento da entrevista, Sandra tinha dois empregos: durante o dia, trabalhava em uma loja de materiais esportivos, em um shopping; aos finais de semana, trabalhava como caixa em uma casa noturna. E se observarmos a sua trajetória, perceberemos a gradual ascensão social que se configura na sucessão dos empregos por ela obtidos.

O modo como, ao longo dessa trajetória, Sandra construiu e alimentou vínculos em espaços institucionais (como o da vida profissional) impactou no tipo de trabalho a que ela teve acesso e no tipo de contato que Ihe propiciou novas dicas de trabalho. Esses contatos, em sua maioria, não são locais e nem vêm de suas esferas primárias; ou seja, estamos longe da homofilia social que perpassara todas as descrições de casos na sessão anterior.

Outra característica que diferencia Sandra da configuração anterior de casos: em seu discurso, ela deixa claro que sua rede pessoal é sempre intencionalmente mobilizada na procura por emprego. Em diversos momentos da entrevista, Sandra relata pedidos feitos a seus contatos no sentido de intermediarem, em seu benefício, uma vaga nos lugares em que eles estavam trabalhando. Com efeito, das sete dicas de emprego recebidas de pessoas de sua rede, cinco vieram de contatos de seu trabalho atual ou de contatos que se vinculam a algum dos trabalhos anteriores. Sandra é explicita no modo de tematizar o papel dos contatos, em geral, e em especial na sua carreira profissional:

"Sandra: Hoje em dia emprego é "QI", emprego "QI", é "Quem Indica". A maioria dos meus empregos é quem indicou".

Conquanto jovem, Sandra já tem uma trajetória ocupacional bastante longa. Foram 16 empregos em 13 anos de vida ocupacional. Essa característica a ajuda a tecer mais contatos profissionais. Mas, some-se a isto, o fato de ter pedido demissão de oito desses empregos, motivada pela busca de empregos de melhor qualidade. Sandra tem, assim, uma postura ativa no que diz respeito à sua trajetória ocupacional. Mas, a possibilidade de abrir mão de empregos com o intuito de conseguir posições ocupacionais mais favoráveis também pode estar associada à posição de Sandra em sua família. Como Francisco, e diferentemente de Dulcinéia, 
REDES- Revista hispana para el análisis de redes sociales

Vol.22,\#6, Junio 2012

http://revista-redes.rediris.es

Sandra é solteira, não tem filhos e, além disso, vive com uma irmã que também trabalha. Desse modo, sua posição familiar lhe permite abrir mão de trabalhos que não a satisfaçam, mesmo que para isso seja preciso passar por períodos de desemprego.

O caso de Sandra ilustra, assim, como as características dos contatos de uma rede, notadamente o modo como vínculos são estabelecidos e, sobretudo, mantidos, podem ser mecanismos decisivos a deslindar a maneira pela qual a rede pessoal pode interferir na trajetória ocupacional. Nesse sentido, não basta conhecer o tamanho e número de esferas de uma rede para avaliar o tipo de informação que ela pode gerar e, menos ainda, o modo como ela pode ser mobilizada pelos agentes.

Elisabete, 50 anos no momento da entrevista, nasceu em Goiânia e se mudou com os pais para São Paulo quando tinha apenas um ano de idade. É parda, solteira e não tem filhos. Quatro características a diferenciam dos demais. Ela cursou ensino superior (Administração); ocupou, na sua trajetória profissional, diversos cargos de chefia; embora trabalhando, já se havia aposentado por tempo de serviço. É também a mais velha dentre os entrevistados, o que a faz pertencer a uma geração diferente. Mais que isso, no momento em que a encontramos, em busca por emprego em agência, ela já tinha uma longa trajetória que incluía empregos de qualificação superior àqueles que ela poderia obter por esse meio de busca.

Sua rede é grande (62 contatos e 321 vínculos) e pouco densa $(0,0794)$. Além disso, nela inexiste localismo: apenas $25,8 \%$ dos contatos moram em seu bairro e menos da metade mora entre seu bairro e bairros vizinhos. Tampouco é socialmente homofílica; parte de seus contatos apresenta condições econômicas privilegiadas e mora em locais nobres e centrais da região metropolitana de São Paulo. Tudo isso revela que a entrevistada circula por vários espaços, tem acesso a grupos sociais com características socioeconômicas distintas das suas, o que aumenta a probabilidade de ter acesso a informações diversificadas em relação ao trabalho. 

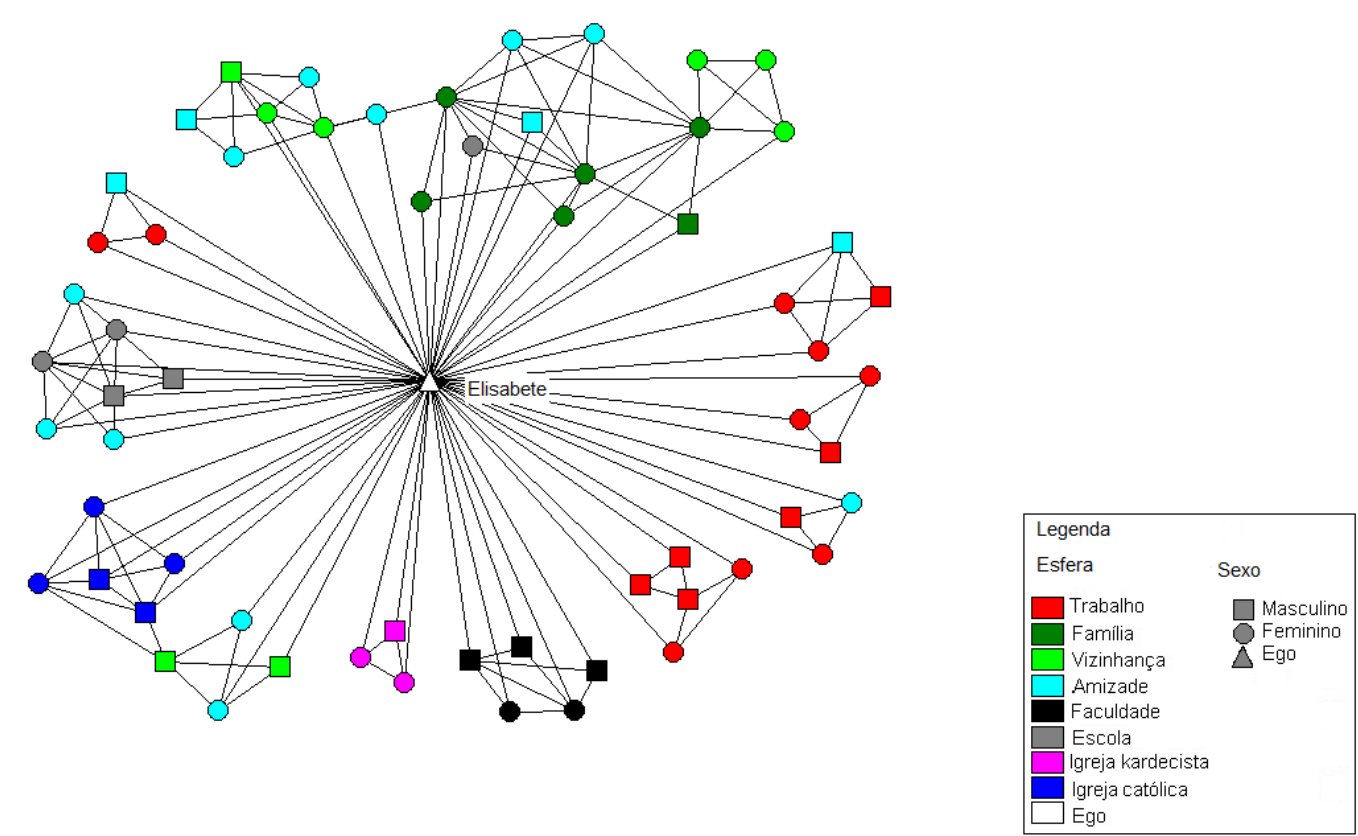

Gráfico 6. Sociograma da rede pessoal de Elisabete

Assim como Sandra, vê-se que Elisabete possui uma rede pessoal rica em contatos obtidos em espaços institucionais que estão para além dos seus vínculos primários; são colegas do ensino superior ou mesmo colegas de classe do colegial, com os quais havia convivido há mais de 30 anos. Na esfera dos contatos constituídos nos espaços de sociabilidade ligados à sua vida profissional estão incluídos, ao lado de colegas do trabalho atual (naturalmente, a maioria), alguns amigos cultivados em empregos que exercera 15 anos antes.

Não sem razão, na sua trajetória ascensional, os trabalhos foram predominantemente obtidos através da sua rede; e nisso novamente se assemelha a Sandra, de que tratamos antes, e Rogério, que apresentaremos a seguir. Assim, Elisabete foi indicada por seus contatos para seis de seus dez empregos; destes, apenas dois (significativamente, os dois primeiros de sua trajetória; o primeiro deles, por indicação paterna) não eram registrados e nos quatro outros casos as indicações the renderam acesso a cargos de chefia. Ademais, o fato de ter exercido funções de chefia e de freqüentemente trabalhar em setores valorizados (financeiro e recursos humanos, por exemplo) parece ter the proporcionado a chance de conhecer pessoas, muitas também em cargos de chefia, capazes de lhe fornecer boas indicações de trabalho. Elisabete tem consciência de que os colegas, nos ambiente de trabalho, foram importantes para a obtenção de empregos e para a construção de sua trajetória: 
REDES- Revista hispana para el análisis de redes sociales

Vol.22,\#6, Junio 2012

http://revista-redes.rediris.es

"Entrevistadora - (...) você já saiu da "Empresa I" [nome fictício] direto pra outra, por indicação de um colega de trabalho?

Elisabete - Por indicação de um colega de trabalho. Sempre fui; só procurei emprego quando eu fui pro [Hospital], o tempo do [Hospital] e esse último [grande período de desemprego]. Sempre tive alguém me indicando, sempre teve alguém vendo o meu trabalho e passando pro outro. Não tive dificuldade. (Grifos nossos)"

Curiosamente, em momentos de desemprego, ela recorreu predominantemente a mecanismos mercantis. Todavia, a última posição que ela obtivera via agência de emprego não apenas a retirou do ciclo de ascensão em cargos de chefia, como a fez regredir. Um resultado distinto daqueles obtidos quando, antes, conseguia trabalho através dos seus contatos; estes Ihe haviam permitido transitar, entre empresas e cargos de chefia, mesmo ainda estando empregada. O trecho abaixo ilustra esse momento especial da trajetória da entrevistada que é, a seu ver, também um momento de instabilidade nos percursos dos colegas que identifica como "a sua equipe"; mas ilustra também a sua convicção de que os vínculos profissionais que provêm boas indicações são os recentes, os "dos últimos empregos".

"Elisabete - Aí eu fui pro mercado procurar trabalho.

Entrevistadora - Tá, foi o período que tava procurando.

Elisabete - Período crítico, de porta em porta; você vai, bate, faz entrevistas, testes. Fui no Centro do Trabalhador, fui de porta em porta, fui por indicação, aí somem as indicações, né? [Risos]. Ué, porque o que acaba indicando também são seus últimos empregos, a minha turma tava tudo na mesma situação que eu, todo mundo na mesma situação que eu. Todo mundo procurando emprego, a minha equipe toda. Algumas se encaixaram em algum cliente, mas eram serviços mais, (como se diz?) mais de montagem, de linha de produção, não pra área de chefia pra cima. Tanto é que quando eu fui pra esse agora, esse emprego, tive que "baixar a minha carteira", "baixei a minha carteira em 100\%". (...) Porque não tinha! dentro da minha faixa de salário eu não consegui! E eu tentei por muito tempo dentro, ou o melhor; a gente tá sempre querendo progredir, melhorar, não regredir. Mas eu não tive jeito não, eu tive que regredir em termos de salário, em termos de função, tudo! eu voltei, você vê, minha carteira tá... Era, na época, tava mais ou menos com 2 e meio; voltei pra um e meio! Sabe, uma coisa bem defasada pra mim voltar no mercado; mas como faltava pouco, eu tinha que trabalhar, faltava pouco pra mim me aposentar, eu tava com 42 nessa época; em 2006, eu tava com 46 com 48, já podia me aposentar. (...) Aí o negócio foi se sujeitar, qualquer salário, qualquer coisa pra voltar no mercado".

Consciente da importância dos contatos e dos seus limites para mobilizá-los, Elisabete encontra ali a razão para a quebra no padrão ascensional da sua trajetória. Nos momentos em que seus contatos não foram eficientes na indicação de trabalho, ela teve de recorrer a outros meios de busca. Nessas ocasiões, fez uso 
REDES- Revista hispana para el análisis de redes sociales

Vol.22,\#6, Junio 2012

http://revista-redes.rediris.es

de meios mercantis, como as agências, ou saiu a campo, em prospecção direta junto a firmas. Mesmo sabendo que os empregos oferecidos pelas agências poderiam ser mais mal remunerados e de mais baixa qualidade do que muitos dentre os que tivera em sua trajetória, Elisabete investia nesse mecanismo de busca, um dos poucos que the restaram quando sua rede falhou. Esse caso ilustra, assim, uma das vias pelas quais se podem articular os mecanismos mercantis e não mercantis no curso das trajetórias individuais.

Rogério, branco e jovem, completara 26 anos quando o reencontramos para a nova entrevista. Era solteiro, não tinha filhos e vivia só. Natural da cidade de São Paulo, havia terminado o ensino médio e iniciara um curso superior em logística que, de acordo com ele, teve de interromper por conta da dificuldade em conciliá-lo com o trabalho.

Tal qual Sandra, Rogério também passou por muitas ocupações - nada menos que oito em um lapso de doze anos. Ambos se mostraram articulados, bastante extrovertidos na entrevista, ela própria uma situação de apresentação de si frente a estranhos, e talvez, por isso mesmo, um proxy, do modo como desempenham nas situações de recrutamento. Daí nossa intuição de que provavelmente os dois detêm, mais que outros entrevistados, os códigos de conduta requeridos na busca por trabalho.

Os contatos foram cruciais na trajetória de empregos ocupados por Rogério; mais ainda que no caso de Sandra. Todos os que obteve, registrados ou não, vieram de indicações certeiras. Isso justifica a sua manifesta consciência acerca da importância das redes, que aciona racional e estrategicamente, assim como Sandra, mesmo quando está em uma ocupação:

"Rogério - Hoje eu não entrego mais [currículo] pessoalmente; por eu estar trabalhando, quero sempre procurar uma coisa melhor. Então, é só Internet, Internet e vou mandando. E o "QI", hoje eu acredito no "QI", se eu fiz amizade com uma pessoa e a pessoa falou: "Tô precisando de uma pessoa." "Opa, maravilha!" "Não, mas você não tem experiência!" "Eu me viro, deixa comigo!"

(...)

Entrevistadora - E, por contatos?

Rogério - Internet quem faz é a minha namorada; ela vai lá, tem o meu currículo e já sai mandando. E eu só no "tête à tête". Eu atendo, eu trabalho no bar, então, vão muitos clientes lá, é um restaurante de classe alta. Então, sempre estou conversando, não que eu chego: "Arruma um emprego pra mim". Não, é antiético isso, mas, porra: "E ai? Você trabalha com o que mesmo? ah, que legal! E como é? Precisa de experiência pra trabalhar? Acho que não, né?" E vai desenrolando o cara ali. 
REDES- Revista hispana para el análisis de redes sociales

Vol.22,\#6, Junio 2012

http://revista-redes.rediris.es

Entrevistadora - Tá. Então, você está sempre antenado pra essas coisas.

Rogério - Sempre, sempre, sempre.

(Grifos nossos)"

Essa busca ativa e estratégica por emprego através de contatos é uma das características que parece tornar sua trajetória ocupacional menos insegura e vulnerável que a de Dulcinéia, por exemplo. Entretanto, embora busque por indicações recorrendo até mesmo aos clientes de seu trabalho atual, os contatos que Ihe renderam dicas certeiras eram pessoas com quem Rogério parecia manter, ou ter mantido, relações freqüentes e fortes; com exceção de um contato que ele conhecera no trabalho, os demais eram seus vizinhos ou familiares. E isso o faz diferente de Sandra e Elisabete, para quem os vínculos primários foram efetivos apenas no início de suas trajetórias; e o aproxima do grupo tratado na sessão anterior, notadamente Dulcinéia e Francisco, cujas trajetórias ocupacionais eram vulneráveis.

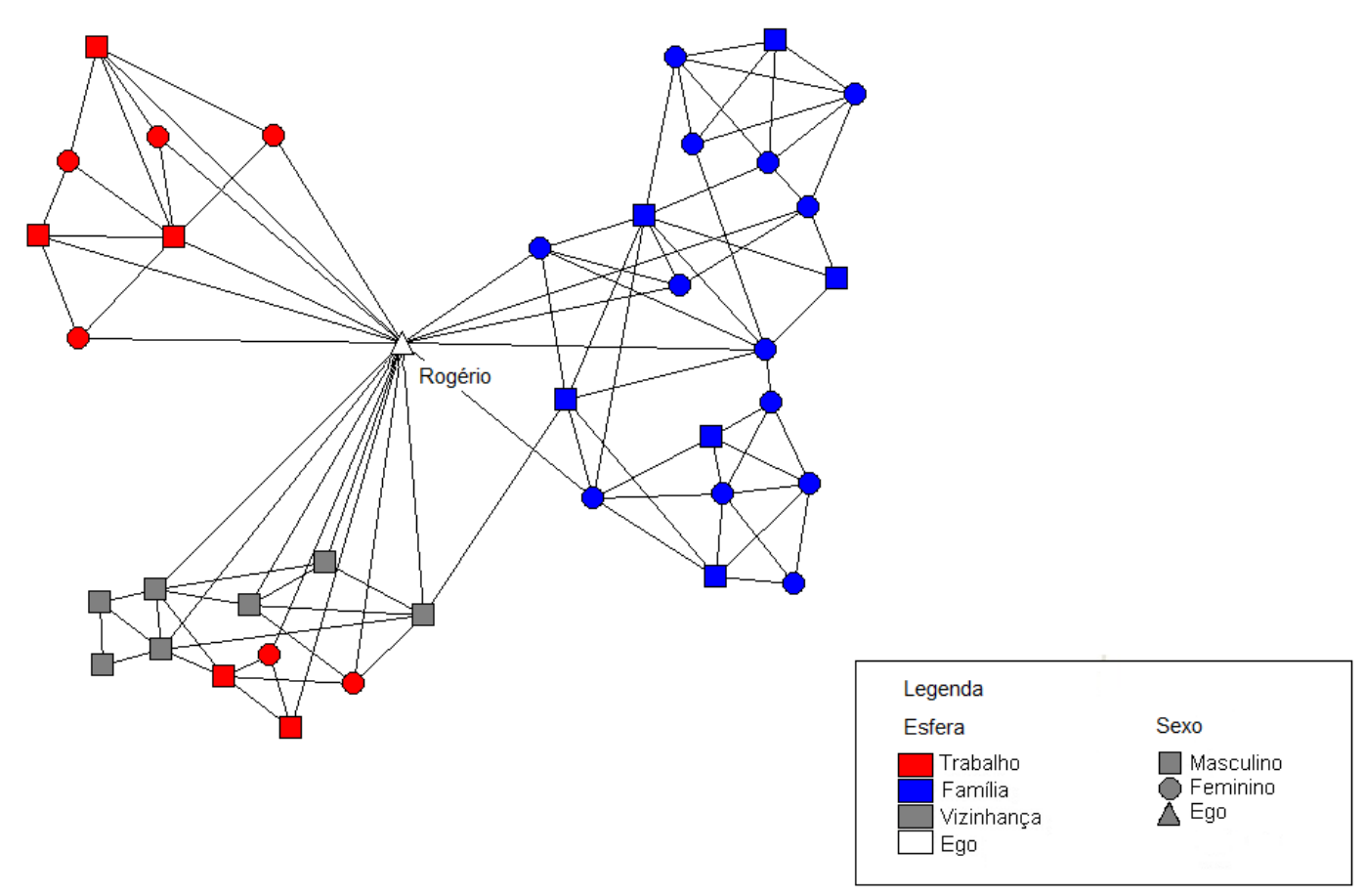

Gráfico 7. Sociograma da rede pessoal de Rogério 
REDES- Revista hispana para el análisis de redes sociales

Vol.22,\#6, Junio 2012

http://revista-redes.rediris.es

Rogério se assemelha a Dulcinéia e Francisco, e mesmo a Vanda, nas características da sua rede pessoal: média (38 contatos, 188 vínculos e densidade 0,1337), com poucas esferas (família, vizinhança e trabalho), marcada pelo localismo (59,4\% dos contatos ou moram em seu bairro ou em bairro vizinho), e socialmente homofílica (mais da metade de seus contatos ou teve eventos de trabalho nos mesmo cargos ocupacionais que ele ou mora no bairro em que ele viveu por toda a vida). Todavia, diferentemente daqueles, a homofília no que respeita à origem social dos seus contatos não opera como um obstáculo às suas iniciativas no mercado de trabalho, haja vista a origem social em meios de classe média estabilizada, tanto do próprio Rogério, como de seus contatos.

Nesse sentido, ter acesso a informações provindas de contatos socialmente semelhantes tem um sentido diferente daquele observado anteriormente, em casos como os de Dulcinéia ou Francisco. Em casos como o de Rogério, a rede pessoal de indivíduos de classe média mostra-se capaz, como já documentado em outros estudos, de gerar informações mais diversificadas, visto que as suas relações transcendem o espaço em que vivem (Marques, 2010).

Damaris, nosso oitavo e último caso, é a mais jovem dentre eles, com 22 anos quando foi entrevistada. Nasceu e vive em São Paulo. Solteira, tem uma filha, e juntas moram com a mãe e os irmãos. Havia terminado o ensino médio e, no Brás $^{21}$, bairro em que trabalhava, havia feito uma série de pequenos cursos sobre comércio e vendas.

Tal como Sandra, Elisabete e Rogério, Damaris teve também uma trajetória ocupacional ascendente. Começou sua vida profissional trabalhando como vendedora temporária em lojas de shopping e como "camelô". Em um curto espaço de tempo, passou por uma série de empregos no comércio, tendo, ao fim, obtido um trabalho registrado em uma loja de roupas no Brás. No início de sua carreira, ainda antes de completar 18 anos, Damaris costumava buscar emprego em agências. Essa estratégia, no entanto, não gerava resultados, o que a fez abandoná-la. Acionar contatos passou a ser, desde então, o mecanismo central de procura e obtenção de trabalho.

Embora a sua rede pessoal seja uma das maiores coletadas por essa pesquisa, com 123 contatos e 632 vínculos (densidade 0,0414), é, como no caso de Rogério, uma das redes mais locais dentre os casos que compõem essa segunda configuração, já que mais de $60 \%$ de seus contatos vivem no seu bairro. Sua rede apresenta

\footnotetext{
${ }^{21}$ Bairro da zona central de São Paulo em que o comércio ligado ao setor de confecções e vestuário está fortemente presente.
} 
REDES- Revista hispana para el análisis de redes sociales

Vol.22,\#6, Junio 2012

http://revista-redes.rediris.es

características que tenderiam a dificultar o acesso a novas oportunidades de trabalho, como o seu localismo, e outros elementos que facilitariam este acesso, como o tamanho e, logo, o número de vínculos por ela abarcados. Quando observamos o que, de fato, essa rede gerou para Damaris, vemos que predomina a influência positiva em sua trajetória: sua rede de contatos não apenas lhe forneceu diversas informações sobre oportunidades de emprego, como, efetivamente, seis de seus sete trabalhos foram obtidos via indicações de conhecidos. Mais do que um mecanismo importante de obtenção de empregos, Damaris reconhece na rede um mecanismo importante na procura por trabalho; e é notável a sua clareza estratégica:

Damaris - "E a maioria dos meus amigos é assim: pra conseguir emprego hoje em dia você tem que ter alguém que te indique, tem que ser uma ótima indicação e você tem que saber o que você está fazendo ali dentro. Então, é bem complicado".

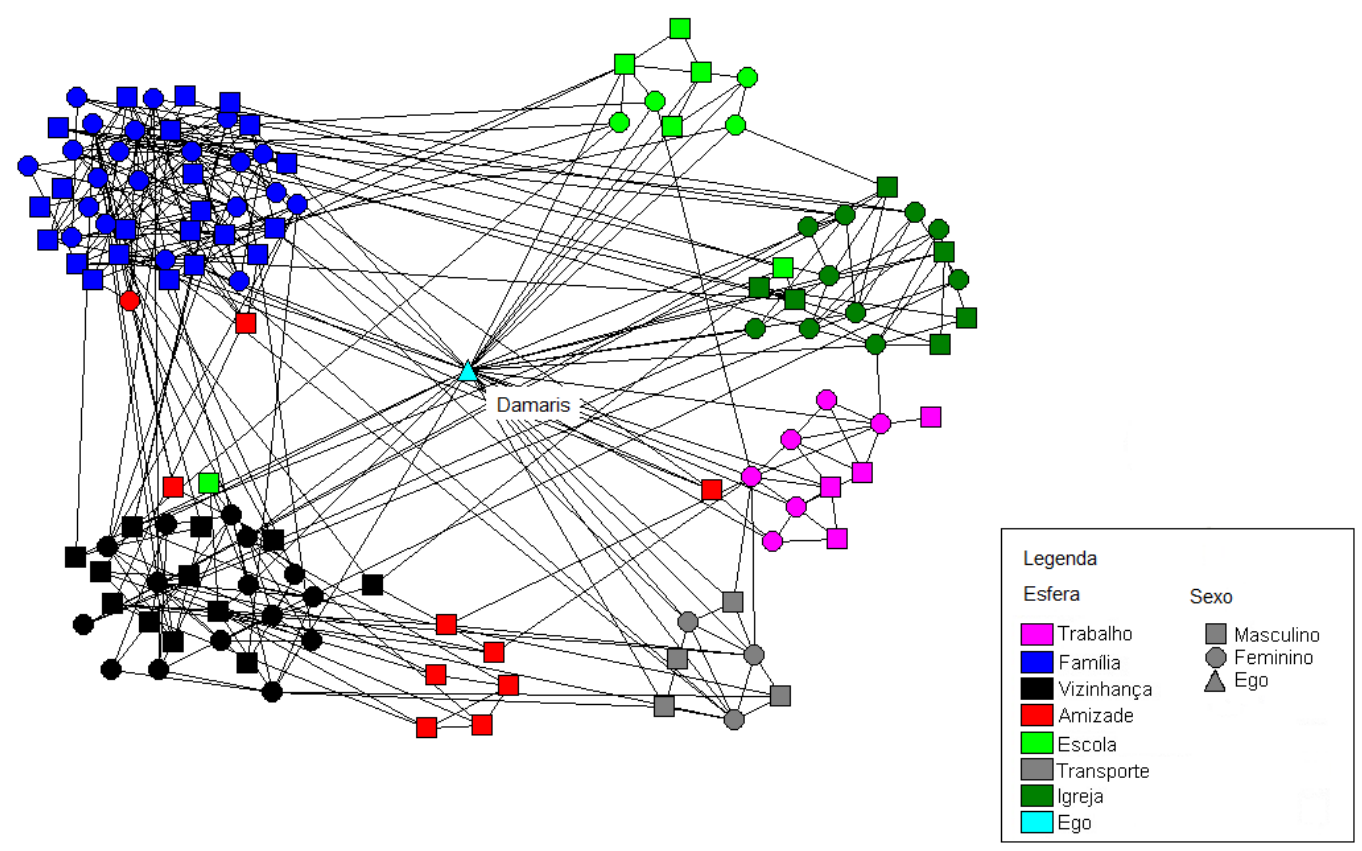

Gráfico 8. Sociograma da rede pessoal de Damaris

Mas, como comparar Damaris e Francisco, cuja rede era também uma importante fonte geradora de trabalho? Por um lado, para ambos as informações de trabalho vieram de contatos muito próximos. Vale dizer: apesar de terem estruturas de rede muito diferentes (com respeito ao número de nós), a informação ocupacional provem da mesma área da rede, a saber dos seus contatos homofílicos. A diferença entre Damaris e Francisco pode estar ligada seja à diferença entre as suas ocupações (ou seja, ao segmento de inserção no mercado), seja à pertinência (tal 
REDES- Revista hispana para el análisis de redes sociales

Vol.22,\#6, Junio 2012

http://revista-redes.rediris.es

como subjetivamente por eles avaliada) das informações geradas por suas respectivas redes. Assim, Francisco queria encontrar trabalhos em áreas diferentes da sua, mas sua rede lhe proporcionava apenas trabalhos na construção civil; por isso mesmo, ele se via forçado a recorrer a outros mecanismos de procura, como as agências de emprego. Já Damaris buscava empregos no comércio e era esse tipo de emprego que sua rede podia Ihe oferecer; boa parte da família de Damaris trabalha no bairro do Brás, região movida pelo comércio de roupas, e, portanto, pode the fornecer informações variadas sobre empregos nessa área, inclusive empregos com registro em carteira. Mas, e por isso mesmo, a rede Damaris também limitou as suas opções de trabalho. Significativamente, no momento da entrevista, ela aguardava ser chamada para uma vaga de inspetora, que havia conseguido via concurso. Assim, foi um mecanismo impessoal que Ihe permitiu sair de sua área ocupacional e dirigir-se a um emprego em que poderia conciliar melhor suas aspirações e necessidades ocupacionais e sua nova condição de mãe.

Se comparamos os quatro últimos casos, vemos que há recorrências interessantes. A mais evidente dentre elas: todos elegeram as redes como o mecanismo mais usual e eficiente de busca por trabalho e, também não por acaso, nesses quatro casos as redes desempenharam um papel importante na inserção ocupacional ou mesmo na mobilidade social desses indivíduos. Vejamos como isso ocorreu com cada um deles.

Observando Rogério, percebemos que pode ser grande a sua aproximação com traços da primeira configuração: afinal, ele tem uma rede pequena (38 contatos) e bastante marcada por vínculos primários. Mas Rogério guarda diferenças significativas com respeito aos quatro primeiros casos abordados: ele é branco e tem origem social em uma família de classe média. Assim, também seus contatos, embora marcados pela homofilia, pertencem a um mundo em que são mais presentes as informações sobre oportunidades de trabalho de melhor qualidade. Além disso, Rogério é solteiro e não tem filhos. Vemos, assim, que não apenas o tamanho ou a diversidade da rede são aspectos importantes para entender o papel por ela desempenhado na trajetória ocupacional do indivíduo; importam também as características ou a origem social desses contatos.

O caso de Damaris também parece bastante semelhante a alguns dos casos do primeiro grupo. Como Francisco e Dulcinéia, a rede de Damaris é bastante profícua no que diz respeito a lhe prover com informações sobre trabalho. E como esses dois outros casos, a experiência ocupacional de Damaris restringiu-se, em grande medida, a um único setor, o comércio. Uma vez que grande parte da família da 
REDES- Revista hispana para el análisis de redes sociales

Vol.22,\#6, Junio 2012

http://revista-redes.rediris.es

entrevistada também trabalha neste ramo, Damaris ali obteve, e com certa facilidade, os seus empregos no setor. Ainda que não tenha investido em qualificação como o fizeram Francisco e Dulcinéia (sua formação se resume ao ensino médio completo) a inserção ocupacional de Damaris é de melhor qualidade. Dois fatores podem ter contribuído para tal; por um lado, as características dos seus contatos, que tinham acesso privilegiado a informações sobre empregos no comércio; por outro lado, os atributos da própria entrevistada: diferentemente de Dulcinéia e Francisco, Damaris era mais jovem e não era migrante, características que podem ter desempenhado um papel positivo na obtenção de um trabalho no comércio.

Sandra, assim como Damaris, não fez grandes investimentos em qualificação. Sua estratégia parece ter sido diferente. Os seus contatos primários não Ihe forneciam tantas informações ocupacionais quanto os de Damaris, mas também neste caso a rede foi um importante mecanismo de busca e obtenção de trabalho. Não eram apenas as esferas de socialização primária - sobretudo a família - que forneciam informações de trabalho a Sandra, mas também as esferas institucionais, as quais Sandra cultivou e mobilizou na sua busca por trabalho ao longo de toda a sua trajetória. A observação do seu percurso nos revela que uma rede rica em informações de trabalho também pode ser fruto de vínculos menos homofílicos, cultivados em esferas institucionais ao longo da trajetória de vida.

Por fim, temos Elisabete, caso em que a mobilidade ascendente parece ser mais clara. Como Sandra, Elisabete também cultivou vínculos criados em esferas institucionais, aos quais recorreu na busca por trabalho. Além disso, ambas são solteiras e não têm filhos; têm, portanto, mais liberdade para investir em suas trajetórias de trabalho. Mas, como alguns casos do primeiro grupo, Elisabete investiu em qualificação. Ela é a única, dentre os entrevistados, a ter cursado ensino superior. $O$ caso de Elisabete conjuga o investimento educacional e o sucesso na mobilização da rede para trabalho, resultando na inserção ocupacional de melhor qualidade dentre nossos casos.

\section{Comentários à guisa de conclusão}

Os casos trazidos para análise parecem ser bons antídotos para hipóteses apressadas que tenderiam a explicar o acesso ao trabalho por uma relação unilateral seja com os atributos, seja com as redes. Ao contrario, eles nos ajudam a deslindar o modo como se tecem os elos entre uns e outras no curso de trajetórias biográficas singulares. 
REDES- Revista hispana para el análisis de redes sociales

Vol.22,\#6, Junio 2012

http://revista-redes.rediris.es

Vimos como essas variadas situações com respeito ao mercado de trabalho, podem ser melhor entendidas - e esse é o ponto que nos interessa:

- seja por diferenças relativas às características sociais das pessoas com as quais construíram e mantiveram vínculos;

- seja por diferenças no modo como cada uma delas mobilizou a sua rede de relações, na busca por trabalho,

- umas e outras variáveis segundo momentos do ciclo de vida e dos seus percursos ocupacionais.

Vale dizer: atributos, relações e percursos devem ser tomados a partir dos nexos que guardam entre si, se quisermos bem interpretar as escolhas e os resultados ocupacionais logrados pelos indivíduos em sua busca por trabalho. Por isso mesmo, há que articular as características individuais às suas formas específicas de tecer vínculos e de mobilizar redes pessoais, formas essas variáveis ao longo de suas trajetórias biográficas.

Poder-se-ia afirmar que os casos-tipo que selecionamos para análise nos municiam a sistematizar cinco argumentos finais, formulados de modo deliberadamente sintético.

Em primeiro lugar, o recurso a redes pode dar acesso e/ou reter indivíduos tanto em trajetórias de estabilidade, quanto em trajetórias vulneráveis.

Em segundo lugar, não há elos virtuosos e prévios entre características das redes (ou dos atributos), por um lado, e os resultados (ou logros) individuais no mercado de trabalho, por outro. Vimos, por exemplo, como mesmo o localismo pode alavancar, ou atravancar, a qualidade da inserção ocupacional.

Em terceiro lugar, as estruturas (de oportunidades e de relações) criam constrangimentos, e estabelecem os graus de liberdade em que os indivíduos se movem.

Entretanto, e em quarto lugar, o modo pelo qual esses circuitos de relações são construídos e acionados está ancorado nas representações construídas pelos indivíduos com respeito ao que foi vivido em suas trajetórias, por um lado, e ao que esperam para si no futuro imediato, por outro. Tais representações lhes dão as boas razões para que teçam (ou não) certas relações e para que as acionem (ou não) em benefício da obtenção de trabalho. 
REDES- Revista hispana para el análisis de redes sociales

Vol.22,\#6, Junio 2012

http://revista-redes.rediris.es

Por isso mesmo, finalmente, e em quinto lugar, inserir-se ocupacionalmente, estar engajado no mercado em ocupações de qualidade pode, por menos que nos pareça razoável, não ser um alvo que oriente a conduta e organize as ações de muitos em nossa sociedade, que costumamos caracterizar como uma "sociedade do trabalho".

\section{Bibliografia referida}

BARR, T. (2009) "With Friends Like These: Endogenous Labor Market Segregation with Homogeneous, Nonprejudiced Agents". American Journal of Economics and Sociology, Vol. 68 (3), July.

Bian, Y. (1997) "Bringing Strong Ties Back in: indirect ties, network bridges, and job searches in China". American Sociological Review, vol. 63 (3), pp. 366-385.

Calvó-Armengol, A.; Jackson, M. O. (2004) "The Effects of Social Networks on Employment and Inequality". The American Economic Review, Vol. 94 (3), June, pp. 426-454.

Brinton, M. e Kariya, T. (2001) "Institutional Embeddedness in Japanese Labor Markets". In: Brinton, M. C. \& Nee, V. The New Institutionalism in Sociology. Stanford: Stanford University Press, pp. 181-207.

Castilla, E.J (2005). "Social networks and employee performance in a call center". American Journal of Sociology Volume 110 (5), March, pp. 1243-83.

Davern, M. e Hachen Jr., D. (2006) "The role of information and influence in social networks: Examining the association between social network structure and job mobility." American Journal of Economics and Sociology, Vol. 65 (2), April.

Durham, E. R. (1973) A caminho da cidade - a vida rural e a migração para São Paulo. São Paulo: Ed. Perspectiva.

Elliot, J. R. (1999) "Social isolation and labor market insulation: network and neighborhood effects on less-educated urban workers". The Sociological Quarterly, vol. 40, n०2, pp. 199-216.

Fernandez, R. e Weinberg, N. (1997) "Sifting and Sorting: Personal Contacts and Hiring in a Retail Bank." American Sociological Review 62, 1997, pp.883-902. Fernandez, R. e Sosa, M. L. (2006) "Gendering the job: Networks and recruitment at a call center." American Journal of Sociology n.111, pp. 859-904.

Franzen, A., and D. Hangartner (2006): "Social Networks and Labour Market Outcomes: The Non-Monetary Benefits of Social Capital," European Sociological Review, n. 22, v.4, pp. 353-368. 
REDES- Revista hispana para el análisis de redes sociales

Vol.22,\#6, Junio 2012

http://revista-redes.rediris.es

Gerber, T. e Mayorova, O. (2010) "Getting Personal: Networks and Stratification in the Russian Labor Market". American Journal of Sociology, v. 116, n. 03, pp. 855908.

Granovetter, M. (1973) "The Strength of Weak Ties". American Journal of Sociology 78 (6), 1973, pp.1360-1380.

Granovetter, M. (1983) "The Strength of Weak Ties: A Network Theory Revisited". Sociological Theory, Volume 1, 1983, pp 201-233.

Granovetter, M. (1988) The Sociological and Economic Approaches to Labor Market Analysis: A Social Structural View. In: Farkas, G. e England, P. (Eds.). Industries, Firms and Jobs: Sociological and Economic Approaches. New York: Plenum Press, 1988. P. 187-216.

Granovetter, M. (1994) Afterword 1994: Reconsiderations and a New Agenda. In: Granovetter, M. Getting a Job: a study of contacts and careers. 2ed. Chicago: Chicago University Press, 1994. p. 139-182.

Guimarães, N.A. (2009) À procura de trabalho. Instituições do mercado e redes. Belo Horizonte: Editora Argvmentvm e CERES

GuimarãeS, N. A. e Melo, F.L.B. (2009). Quem recorre às instituições do mercado para encontrar trabalho?. In: Guimarães, N.A . À procura de trabalho. Instituições do mercado e redes. op cit., cap. 5, pp.149-174.

Huffman, M. e Torres, L. (2002) "It's not only 'Who You Know' that matters:

Gender, Personal Contacts, and Job Lead Quality". Gender and Society, v. 16, n.06, pp. 793-813

Ioannides, Y. M. e Loury, L. D. (2004) "Job Information Networks, Neighborhood Effects, and Inequality". Journal of Economic Literature, Vol. 42 (4), pp. 1056-93.

Kirschbaum, C. (2009). Renascença da indústria brasileira de filmes: destinos entrelaçados? Martes, A.C (org.) Redes e Sociologia Econômica. São Paulo: EDUFSCAR, cap. 10 , pp. 309-334.

Lin, N., Ensel, W e Vaughn, J (1981). "Social resources and strength of ties: structural factors in occupational status attainment". American Sociological Review, Vol. 46, August, pp. 393-405.

Marques, E. C. (2010) Redes sociais, segregação e pobreza. São Paulo: UNESP.

Marques, E.C.; Bichir, R.; Zoppi, M; Moya, E.; M.Pantoja, I. (2006). "Redes Pessoais e Pobreza em São Paulo. São Paulo: Centro de Estudos da Metrópole". Consultado em: 
REDES- Revista hispana para el análisis de redes sociales

Vol.22,\#6, Junio 2012

http://revista-redes.rediris.es

http://www.cebrap.org.br/v2/files/upload/biblioteca virtual/MARQUES\%20et\%20al Redes\%20Pessoais\%20e\%20Pobreza.pdf

Martes, A. C e Rodriguez, C.L. (2004). "Afiliação religiosa e empreendedorismo étnico: o caso dos brasileiros nos Estados Unidos". Revista de Administração Contemporânea. V.8 (3), pp. 117-141.

McDonald, S. (2010) "Right place, right time: serendipity and informal job matching". Socio-Economic Review, 8, 307-331.

McDonald, S.; Lin, N. e Ao, D. (2009) "Networks Opportunity: gender, race, and job leads". Social Problems, Vol. 56, No. 3, pp. 385-402.

Mcpherson, M.; Smith-Lovin, L; Cook, J. M. (2001) "Birds of a feather: homophily in social networks". Annual Review of Sociology v. 27, pp. 415-44.

Moerbeek, H. e Need, A. (2003) "Enemies at work: can they hinder your career?" Social Networks 25, pp. 67-82.

Mouw, Ted. 2003. "Social Capital and Finding a Job: Do Contacts Matter?" American Sociological Review 68, pp. 868-98.

Neckerman,K e Fernandez, R. (2003) "Keeping a job: network hiring and turnover in a retail bank". In: Vincent Buskens, Werner Raub, and Chris Snijders (ed.) The Governance of Relations in Markets and Organizations (Research in the Sociology of Organizations, Volume 20), Emerald Group Publishing Limited, pp.299-318.

Petersen, T.; Saporta, I.; Seidel, M. L. (2000) "Offering a Job: Meritocracy and Social Networks". American Journal of Sociology, Vol.106 (3), pp.763-816.

Podolny, J. e Baron, J. (1997) "Resources and relationships: Social networks and mobility in the workplace". American Sociological Review, Vol. 62, p. 673-693.

Seidel, M. Polzer, J. e Stewart, K. (2000) "Friends in high places: The effects of social networks on discriminations in salary negotiations". Administrative Science Quarterly. Vol. 45, No. 1, pp. 1-24.

Stovel, K.; Fountain, C.. (2008) "Hearing about a job". Draft Version.

Vieira, P.P.F (2009) A experiência da procura de trabalho: um estudo de caso. S.P., Dissertação de Mestrado, Programa de Pós-Graduação em Sociologia da USP.

Tassier, T. (2006) "Labor market implications of weak ties". Southern Economic Journal, 72 (3). 
REDES- Revista hispana para el análisis de redes sociales

Vol.22,\#6, Junio 2012

http://revista-redes.rediris.es

Truzzi, O. e Sacomano Neto, M. (2007) "Economia e empreendedorismo étnico: balanço histórico da experiência paulista". RAE - Revista de Administração de Empresas, vol 47 (2), pp. 37-48.

Weneger, (1991) "Job Mobility and Social ties: Social Resources, Prior Jobs and Status Attainment". American Sociological Review, v.56, Feb., pp. 60-71

Yakubovich, V. (2005) "Weak Ties, Information, and Influence: how workers find jobs in a local Russian labor market". American Sociological Review, Vol. 70 (June), pp. 408-421. 